\title{
L'evolució de la població de Catalunya als segles XVI i XVII. Estancament, crisi i creixement
}

\author{
Llorenç Ferrer Alòs* \\ Universitat de Barcelona
}

\section{Resum}

La manca de recomptes sobre la població de Catalunya al segle Xvir l'ha convertit en un segle difícil d'estudiar. En aquest treball es proposa la utilització massiva de sèries parroquials per revisar l'evolució demogràfica d'aquest segle i intentar explicar-la. Aquesta evolució es caracteritza per un estancament provocat per una profunda crisi a mitjan segle i per una recuperació cap al final. L'explicació la trobarem en l'elevada mortalitat, especialment la catastròfica i una fecunditat moderada. S'aporten també dades sobre el creixement demogràfic del segle xvi.

Paraules clau: Demografia, Catalunya segles XVI-XvII, evolució demogràfica, mortalitat, crisi de mortalitat, fecunditat.

\section{La evolución de la población de Cataluña en los siglos XVI y XVII. Estan- camiento, crisis y crecimiento}

\section{Resumen}

La falta de recuentos generales sobre la población de Cataluña ha convertido el siglo XVII en un siglo difícil de estudiar. Este trabajo se propone la utiliza-

* ORCID 0000-0002-403I-880I. Professor de la Secció d'Història Contemporània i Món Actual, Facultat de Geografia i Història. Correu-e: llferrer@ub.edu. Web: https://www.researchgate.net/profile/FERRER_Llorenc. Aquesta recerca forma part del projecte HAR2017-84030-P, Mundos del trabajo en transición (I750I930): cualificación, movilidad y desigualdades. 
ción masiva de series parroquiales para revisar la evolución demográfica de dicho siglo e intentar explicarla. Esta evolución se caracterizará por un estancamiento provocado por una profunda crisis a mediados de siglo y por una recuperación hacia finales. La explicación vamos a hallarla en la elevada mortalidad, especialmente la catastrófica, y en una fecundidad moderada. Se aportan también datos sobre el posible crecimiento demográfico del siglo XVI.

Palabras clave: demografía, Cataluña siglos XVI-XVII, evolución demográfica, mortalidad, crisis de mortalidad, fecundidad.

\title{
Evolution of the population of Catalonia in the I6th and I7th centu- ries. Stagnation, crisis and growth
}

\begin{abstract}
The lack of accounts of the population of Catalonia in the 17 th century has made it a difficult century to study. This paper proposes the massive use of parish records to review the demographic evolution of this century and form an explanation of it. This evolution is characterized by a stagnation caused by a deep crisis in the middle of the century, followed by a recovery towards its end. We develop an explanation for the high mortality rate, and especially the catastrophic and moderate fertility. Data on I6th-century population growth are also provided.
\end{abstract}

Keywords: demography, Catalonia, I6th-I7th centuries, demographic evolution, mortality, mortality crisis, fertility.

Tot i l'existència de bons treballs de síntesi, ${ }^{\mathrm{I}}$ el coneixement de l'evolució demogràfica de la Catalunya dels segles XVI i XVII presenta molts

I. Jordi Nadal i Emili Giralt, "Ensayo metodológico para el estudio de la población catalana de I553 a 1717", Estudios de Historia Moderna, 3 (1953), pp. 239-284; Jordi Nadal i Emili Giralt, La population catalane de I553 à I7I7. L'immigration française et les autres facteurs de son développement, SEVPEN, París, I960 (versió catalana, Eumo, Vic, 2000); Antoni Simon, «La població catalana a l'Ėpoca Moderna. 
clarobscurs. Disposem dels fogatges de 1515 i $1553^{2}$ que compten focs i no població, i ja no tenim cap més recompte general fins el I717, que ha estat posat en qüestió en molts treballs. Entremig ha aparegut un recompte de focs de diversos bisbats: el $1595^{3}$ realitzat per la creació del bisbat de Solsona i un recompte parcial el I 626 de les parròquies del bisbat de Vic. ${ }^{4}$ Aquestes fonts més o menys generals presenten sempre el dubte de la seva fiabilitat, atès que solien elaborar-se per raons fiscals i pel mètode de passar les dades sense cap recompte previ i per la dificultat d'establir un multiplicador que permeti transformar els focs o veïns en nombre d'habitants. Encara que donéssim per bones les dades, aquests recomptes no permeten establir el ritme de creixement de la població catalana. Lúnica manera d'acostar-s'hi és anar a parar a les dades sacramentals que des del Concili de Trento els rectors estaven obligats a recollir. De fet, les dues síntesis que hem esmentat sobre l'evolució demogràfica en aquest període acaben reivindicant la necessitat de recórrer a les sèries parroquials, i l'evolució que defineixen es basa en una petita mostra de les sèries.

Síntesi i actualització», Manuscrits, Io (1992), pp. 217-258; Antoni SIMON, «El redreçament demogràfic del llarg segle Xvi. El paper de la immigració occitana», a Història de Catalunya, L'Esfera dels Llibres, Barcelona, 2004, pp. 356-37I; Antoni Simon, «El creixement poblacional català del segle Xvı i la immigració francesa. Aspectes demogràfics i socials", a Felipe II y el Mediterráneo, vol. I. Los recursos humanos y materiales, Sociedad Estatal para la Conmemoración de los Centenarios de Felipe II y Carlos V, Madrid, I999, pp. 79-98; Jaume DanTí, «La població. Creixement i oscilllacions», a Història. Política, societat i cultura dels Països Catalans. Crisi institucional i canvi social (segles XVI-XVII), Fundació Enciclopèdia Catalana, Barcelona, 1997, pp. 72-89; Valentí Gual, "La demografia catalana al segle XvI», Afers. Fulls de Recerca i Pensament, vol. 23, 60 (2008), pp. 275-288.

2. Josep IglÉsIEs, El fogatge de I553. Estudi i transcripció, 2 vols., Fundació Salvador Vives i Casajoana, Barcelona, 1979; Josep IgLÉsIEs, «El fogatge de I515», Butlletí de la Societat Catalana d'Estudis Històrics, 9 (1998), pp. 23-86.

3. Antoni Simon i Ramon Alberch, «El cens de 1595 . Bisbats de Solsona, Vic i Alt Urgell», Revista Catalana de Geografia, 9-I6, (1980), pp. 80-I03.

4. Antoni Pladevall, "Un cens general de Catalunya fins ara desconegut», Ausa (1973), pp. I29-I42. 
La reconstrucció demogràfica de Catalunya d'aquest segle havia de passar necessàriament per la utilització dels registres parroquials. ${ }^{5} \mathrm{~A}$ partir d'aquí, en el marc d'una tradició de reconstrucció d'estructures socials i econòmiques inspirada en la historiografia francesa, es van generar, d'una banda, tot un seguit de treballs d'àmbit comarcal en els quals la demografia hi tenia un paper important i, de l'altra, treballs estrictament demogràfics basats en aquestes fonts parroquials. ${ }^{6}$ Normalment són treballs quantitatius amb diferents nivells de profunditat, però tots tenen el problema que no arriben a donar una visió general i, d'altra banda, no s'aborda metodològicament el problema de sèries incompletes que dificulten una reconstrucció general de l'evolució de la zona estudiada. El caràcter local i comarcal no ha portat encara a una interpretació general. En pocs casos, es forcen les dades per generar models interpretatius generals que ens donin una visió general de

5. Cal destacar el treball collectiu de recollida de dades que es feu a la Universitat Rovira i Virgili impulsat per Luis Navarro Miralles. Les dades no han estat publicades, però s'han generat moltes recerques a partir d'aquests materials: Antonio Moreno i Luis NAVARro, "La crisis demográfica del siglo XviI en el Baix Camp (I59I-I692)», a Primer Col.loqui d'Història del Camp de Tarragona, Conca de Barberà i Priorat, Institut d'Estudis Tarraconenses, Tarragona, 1979, pp. 49-65; Margarida Gonzalvo, Josep FÀBREgas i Judith VIDAL, «Evolución demográfica del Camp de Tarragona (Cataluña, España) I570-I880: las grandes crisis de mortalidad», Población y salud en Mesoamérica, I4, I (2016), pp. 32-57; Josep M. Morell, Demografia de Reus i la seva àrea d'influència a l'època moderna, Diputació de Tarragona, Tarragona, 1994; Antonio Moreno et al., El original crecimiento de la población en el Camp de Tarragona (I547-I877). Una reconstrucción, Congreso de la ADEH, Albacete, 2013, entre d'altres.

6. Els anys vuitanta i noranta van donar una gran quantitat de tesis i tesines que van treballar registres parroquials que enumerem en l'apèndix final. Hem de destacar l'impuls realitzat en el seu moment a la Universitat de Barcelona per Jaume Dantí i després per Valentí Gual i Antoni Simón i Roser Nicolau a la Universitat Autònoma. Cal destacar també els treballs de Francisco Muñoz utilitzant tècniques més sofisticades demogràficament per acostar-se a l'evolució demogràfica de Catalunya. La recerca sobre els aspectes sanitaris derivats dels arxius parroquials, impulsats per Jacint Corbella des de la càtedra d'Història de la Medicina de la Universitat de Barcelona, ha generat més de trenta tesis doctorals basades en el buidatge dels fets demogràfics d'una bona colla de parròquies de Catalunya. 
Catalunya. ${ }^{7}$ Laltre mètode de reconstrucció de famílies en sentit estricte no ha donat grans fruits a Catalunya per al segle XvII, i sovint les dades resultants són contradictòries i difícils d'interpretar i generalitzar. ${ }^{8}$

Després d'una gran quantitat de treballs locals i comarcals, en la nostra recerca hem volgut agregar totes les sèries parroquials disponibles en aquest moments que corresponen als segles XVI i XVII, i aportar una nova llum a l'evolució demogràfica de Catalunya durant aquest període com també acostar-nos a les causes que el poden explicar. Ens hem limitat a emplenar alguns buits amb la metodologia que explicarem i a mostrar l'evolució de les dades brutes sense gaires pretensions estadístiques.' Algunes sèries són massa fràgils per sotmetre-les encara a més manipulacions. Oferim els nostres resultats sense més pretensions.

7. Francisco Muñoz, «Creixement demogràfic. Mortalitat i nupcialitat al Penedès (s. XVII-XIX)», Universitat Autònoma de Barcelona, I99I. És en aquesta recerca on s'utilitzen metodologies que permeten reconstruir l'evolució demogràfica del Penedès.

8. Joan M. SERra, «La demografia de Balsareny al segle XVII», Dovella, I982, I822; M. Teresa Ferrer, «Resultat de l'estudi de la fecunditat a una parròquia catalana: Sant Feliu de Llobregat al segle XvII", Manuscrits. Revista d'Història Moderna, 2 (1985), pp. I29-I44; Pilar GARCIA et al., "Comportamiento demográfico en torno a la fecundidad en la Abrera del siglo XviI", en Primer Congrés d'Història Moderna de Catalunya, Universitat de Barcelona, Barcelona, I984, pp. IOI-IO9; Àngels Torrents, «Transformacions demogràfiques en un municipi industrial català: Sant Pere de Riudebitlles (I608-1935)", tesi doctoral inèdita, Universitat de Barcelona, I993; Raimon Masdéu, Reconstrucció de famílies de la parròquia de Sant Just Desvern (I509-I936). Un estudi de demografia històrica, Universitat Autònoma de Barcelona, Bellaterra, 2016; Valentí GuaL, «Balanç natural i reconstrucció de famílies a través dels sagramentaris. La Conca de Barberà a l'època moderna», tesi doctoral, Universitat de Barcelona, I99I i Vida i mort a la Conca de Barberà a l'Edat Moderna (Rocafort de Queralt s. XVIXVIII), Institut d'Estudis Tarraconenses Ramon Berenguer IV, Tarragona, I988; Josep M. Planes, Demografia i societat de Tàrrega i de l'Urgell durant l'Antic Règim. L'autor, Agramunt, I995; Josep M. Comas PiÉ, Vila-rodona a l'època moderna. Una societat rural d'Antic Règim, Silva Editorial, Vila-rodona, 2014.

9. De fet aquest treball és la conseqüència dels estudis sobre demografia que estem fent per a Catalunya sobre els segles XVIII i XIx. En la mateixa recerca de dades hem acabat recollint també una important quantitat d'informació sobre el segle XVII que ens ha semblat que havíem de posar a disposició, tot i ser conscients que aquest període històric no és el que treballem habitualment. 


\section{La fiabilitat dels recomptes dels segles XVI $i$ XVII}

Són fiables els fogatges i recomptes que tenim dels segles XVI i XVII? No és facil mesurar-ho, entre altres coses perquè solen comptar focs (llars) i el gran problema que es presenta és quantes persones vivien de mitjana per foc i per quant cal multiplicar-ho. Si tinguéssim la població podríem més o menys establir les taxes de natalitat i podríem determinar-ne la fiabilitat. Per acostar-nos a aquesta pregunta hem recollit, en el quadre I, la relació entre els habitants teòrics de les parròquies de què tenim naixements, suposant una taxa de natalitat del $40 \%$, amb els focs d'aquestes parròquies, i determinem la relació habitants per foc. Només en el recompte de 1626 podem estimar una taxa de natalitat. ${ }^{\text {Io }}$

Sobre el fogatge de I553, tenim una mostra de parròquies que abasten el i6,6 \% del total de la població, un percentatge que comença a ser significatiu. Treballem amb dades de naixements del voltant de I565, anys després d'elaborar-se el fogatge i durant els quals la població podia haver crescut, i treballem amb una natalitat suposada del $40 \%$. Amb aquests supòsits obtenim una mitjana de 6,8 habitants per foc, amb moltes disparitats segons les regions. La dada no ens resol gran cosa. El problema és saber quin és el multiplicador per convertir els focs en habitants. Tradicionalment s'ha multiplicat per quatre o per cinc, però Jaume Dantí ja ha advertit que segurament s'ha de distingir entre el camp (més habitants per foc) i la ciutat, i que el multiplicador ha de ser més alt que el 5 establert. ${ }^{\text {II }}$ (quadre I)

IO. No realitzem el càlcul per a l'any I5I5 perquè només tenim dades de 14 parròquies i, d'aquestes, de les del Maresme (4) no en disposem, així com de Castelló d'Empúries i les dues de Girona es refereixen només a una part de la ciutat. Respecte al fogatge de $\mathrm{I5} 53$, en una bona part de parròquies hem calculat la població sobre els naixements al voltant de 1565 , ja que no tenim dades anteriors.

II. Jaume Dantí, «La població. Creixement i oscil.lacions», en Història. Política, societat $i$ cultura dels Pä̈sos Catalans. Crisi institucional $i$ canvi social (segles XVI-XVII), Fundació Enciclopèdia Catalana, Barcelona, 1997, pp. 73-74. 
QUADRE I. Fiabilitat dels fogatges i recomptes segons baptismes de les parròquies estudiades

\begin{tabular}{|c|c|c|c|c|c|c|c|c|c|}
\hline & 1553 & & & 1595 & & & 1626 & & \\
\hline & Focs & $\begin{array}{l}\text { Hab. } \\
40 \%\end{array}$ & $\begin{array}{c}\text { Hab. } \\
\text { foc }\end{array}$ & Focs & $\begin{array}{l}\text { Hab. } \\
40 \% \text { o }\end{array}$ & $\begin{array}{c}\text { Hab. } \\
\text { foc }\end{array}$ & $\begin{array}{l}\text { Naix } \\
\text { parr }\end{array}$ & $\begin{array}{l}\mathrm{Hab} \\
\mathrm{I} 626\end{array}$ & TBN \\
\hline regió I & I. 493 & 13.900 & 9,3 & & & & & & \\
\hline regió 2 & 2.882 & I 5.245 & 5,3 & & & & & & \\
\hline regió 3 & I. 836 & $\mathrm{I} 2.376$ & 6,7 & & & & & & \\
\hline regió 4 & I. 724 & II. 728 & 6,8 & & & & 53,5 & I.234 & 43,4 \\
\hline regió 5 & I.I56 & 5.649 & 4,9 & & & & & & \\
\hline regió 6 & $5 \mathrm{I} 2$ & 4.663 & $9, \mathrm{I}$ & I. 458 & 8.966 & $6, \mathrm{I}$ & 187,5 & 4.I44 & 45,2 \\
\hline regió 7 & 932 & 8.083 & 8,7 & I. 425 & $7.33 \mathrm{I}$ & $5, \mathrm{I}$ & 190,2 & $5.29 \mathrm{I}$ & 35,9 \\
\hline regió 8 & 594 & 4.224 & $7, \mathrm{I}$ & 150 & I.I74 & 7,8 & & & \\
\hline regió 9 & & & & 400 & 1.706 & 4,3 & & & \\
\hline $\begin{array}{l}\text { Total } \\
\text { estudiat }\end{array}$ & II.I29 & 75.866 & 6,8 & 3.433 & I9.I77 & 5,6 & $43 \mathrm{I}, 2$ & 10.669 & 40,4 \\
\hline $\begin{array}{l}\% \\
\text { estudiat }\end{array}$ & I 6,6 & & & $\mathrm{I} 4,8$ & & & & 20,8 & \\
\hline
\end{tabular}

Si acceptéssim que els focs totals que tenim de Catalunya són correctes i que el multiplicador que s'hauria d'aplicar és 6,8 (corrector que ja seria una manera d'esmenar els errors del mateix recompte), la població estimada per aquest any seria de 456.456 habitants, més o menys la xifra que obtindrem més endavant amb altres mètodes. Això significa un $36 \%$ més de la població que resulta de multiplicar per 5 el nombre de focs.

El fogatge de 1595 va ser elaborat en el moment de constituir la diòcesi de Solsona. No hi havia cap motiu fiscal, sinó el càlcul de com quedarien les noves diòcesis, per això podria ser més real i objectiu. Però és parcial i afecta la Catalunya central, les terres de Lleida i la Catalunya pirinenca. Del total de focs d'aquest recompte, tenim dades demogràfiques parroquials que corresponen al i4,8 \% dels focs. En aquest cas ens dona un multiplicador de 5,6, millor que el de I553. Ens fa pensar que fou un recompte més fiable. 
Finalment, tenim un recompte parcial de 1626 que afecta el bisbat de Vic. Com que ens dona dades de població, podem estimar quina era la taxa de natalitat aquest any a partir de relacionar-ho amb els baptismes que tenim d'algunes parròquies. Ho hem fet amb dades del $20,8 \%$ del total del bisbat. El resultat ens indica que aquest recompte és molt fiable en general, ja que la taxa de natalitat dels pobles estudiats és del 40,4\%o, dins dels paràmetres lògics d'aquesta taxa i que ens permet utilitzar-la com a base per estimar la població als segles XVI i XVII, com veurem més endavant.

\section{L'evolució dels naixements i la població als segles XVI $i$ XVII}

Hem recopilat de manera pacient les sèries demogràfiques de naixements, defuncions i casaments que hi havia reconstruïdes a Catalunya en treballs diversos. ${ }^{\mathrm{I2}} \mathrm{A}$ ningú se li escapa que, com més enrere anem en el temps, menys completes i potser menys fiables són. Tot i que hem aplegat sèries parcials, el criteri per utilitzar-les ha estat que havien de començar com a mínim l'any I600 i ser completes fins el I700, on ja enllacem amb una altra recerca que reconstrueix l'evolució demogràfica de Catalunya al segle XVIII. ${ }^{13}$ Hem recollit també les sèries de naixements que començaven al segle XVI, a fi i efecte de veure si ens podíem acostar a l'evolució demogràfica d'aquesta centúria.

Tot i que els llibres sacramentals van ser imposats com a obligació a partir del Concili de Trento (I563), alguns sínodes realitzats en diferents bisbats ja suggerien als rectors portar llibres de registres. Així, doncs, és possible trobar registres que comencen abans del concili, però de fet es van generalitzar a partir de 1563 i a mesura que s'anaven concretant a cada

I2. Vegeu l'annex adjunt.

13. Llorenç Ferrer-Alòs, «Una transició demogràfica primerenca. Sobre l'evolució demogràfica de Catalunya (segles XVIII-XIX). Fecunditat, mortalitat i moviments migratoris», Recerques, 78 (202I), pp. 27-96. 
bisbat els acords de Trento. ${ }^{\mathrm{I}} \mathrm{El}$ resultat d'aquest procés és que tenim I4 sèries de baptismes que comencen el I5IO ( $5,2 \%$ de la població de I717), 44 el I550 (IO,I \%), 95 el I565 (I8,2 \%) i I83 el I600 (27,I \%), un volum prou important per acostar-nos a l'objectiu que estem plantejant. ${ }^{\text {IS }}$

Metodologia. La metodologia utilitzada ha consistit en l'agregació de sèries de baptismes, defuncions i casaments de parròquies en l'àmbit comarcal, regional i de Catalunya, amb l'única restricció que fossin completes i sense evidències òbvies de mala qualitat. A partir d'aquí hem procedit de la manera següent:

I. Algunes sèries de naixements presenten buits puntuals d'uns pocs anys que hem refet calculant la mitjana aritmètica dels quatre anys anteriors i dels posteriors de què tenim dades. Si el buit és més gran, o hem desestimat la sèrie o hem procedit a reconstruir-la seguint la tendència que manifestaven les sèries de naixements de la comarca ${ }^{16}$ No hem aprofitat sèries parcials sobre algunes parròquies ja que s'ha prioritzat que la sèrie abracés tot el segle.

En relació a les sèries del XVI, que no sempre començaven el 1550 o el 1565 sinó alguns anys després, les hem reconstruït amb el sistema d'adjudicar valors a partir de les mitjanes aritmètiques dels primers

I4. Raimon MASDEU, "Història dels llibres sacramentals (parròquia dels Sants Just i Pastor, Sant Just Desvern, bisbat de Barcelona)", Paratge, 29, (2016), pp. 49-60.

I5. Lleida disposa d'una excel.lent sèrie pel segle xvi que s'acaba a començament del segle Xvir quan els baptismes es van distribuir entre les parròquies de la ciutat. No tenim per tant la continuïtat (per al segle xvir només Sant Joan de Lleida). Tot i que el criteri per reconstruir l'evolució dels baptismes ha estat que les sèries tinguessin continuïtat fins al I700, hem fet una excepció en el cas de Lleida, ja que s'inicia a començaments del segle Xvi. Això ens ha obligat a enllaçar les sèries a partir d'encavalcar números índex.

I6. El mètode consisteix a calcular el pes que té la sèrie amb buits sobre la comarca a partir de la mitjana de quatre anys anteriors i posteriors al buit. La diferència entre els dos percentatges es reparteix entre tots els anys buits i es procedeix a estimar el pes que tenia la sèrie en relació amb les dades agregades dels anys que tenim complets de totes les sèries. Amb aquest mètode, l'evolució de la sèrie segueix el ritme de la resta de la comarca i podem aprofitar els anys de què tenim dades. 
anys quan es tractava de pocs buits, a fi de poder tenir una mostra més àmplia.

No disposem d'elements que ens permetin analitzar si una sèrie recull tots els esdeveniments demogràfics de la població, més enllà de canvis sobtats o il.lògics que a vegades s'han pogut esmenar amb la mitjana aritmètica dels anys anteriors i posteriors; ni tenim criteris suficients per determinar les ocultacions típiques que es podien produir derivades del tipus de registre, ni dels naixements dels infants que morien en néixer, ni de les incidències del comportament del rector de cada parròquia. Pressuposem que el volum de dades tendeix a compensar possibles errors que es puguin produir, ja que cal suposar que es generen de manera aleatòria. Només els períodes de guerra o pesta presenten alguns dubtes que plantejarem més endavant. D’altra banda, el que busquem és la tendència general i no el detall, que podria estar alterat per les circumstàncies de cada parròquia.

2. Utilitzarem les sèries de baptismes per pressuposar l'evolució de la població. Els naixements ho reflecteixen, sempre que la taxa de natalitat es mantingui estable al llarg del temps. Aquesta estabilitat no la podem demostrar, tot i que cal pensar que una societat d'Antic Règim es movia en taxes que se situaven entre el $35 \mathrm{i}$ el $45 \%$; no podem preveure, però, els canvis dins d'aquesta forquilla de natalitat. Hem utilitzat de manera genèrica una taxa suposada del $40 \%$, que és la que hem deduït del recompte de I626 analitzat més amunt (quadre I). Així mateix, no sabem com es comportava la població en moments d'emergència social com durant la pesta bubònica de I650-I655 i fins a quin punt podia alterar les sèries.

3. Malgrat aquestes possibles fluctuacions, creiem que els naixements són un bon indicador per aproximar-nos a l'evolució de la població. Podem establir a partir d'aquestes sèries quina era la població de Catalunya. La manca de dades ha provocat moltes especulacions sobre el tema ${ }^{17}$ i, amb aquest volum d'informació, hem cregut que

I7. Jordi NADAL, Bautismos, desposorios y entierros. Estudios de historia demográfica, Ariel, Barcelona, I992; Antoni SImón, «La població catalana a l'Ėpoca Moderna. Síntesi i actualització», Manuscrits, Io (1992), pp. 217-58. 
ens havíem d'atrevir a donar unes xifres. El mètode que hem utilitzat per arribar a la població de Catalunya consisteix en l'elaboració d'una sèrie amb un número índex que encadeni les diferents sèries de naixements que tenim (formades per un volum variable de sèries que disminueix a mesura que anem enrere en el temps) i aplicar aquests números índex a la població que hem estimat per a I7I7 en altres treballs nostres. Aquest mètode ens permet donar xifres aproximades de la població de Catalunya durant el període estudiat i descriure'n els ritmes de creixement.

\section{L'evolució de la població de Catalunya}

La sèrie de naixements de Catalunya compta amb I4 sèries només de I5IO a I550 que es converteixen en 44 a partir de I550 i 98 a partir de I565. Fins a quin punt catorze sèries poden representar l'evolució de Catalunya durant mig segle? La mostra és molt petita i, a més, cinc són de ciutats grans (Lleida, Tortosa, Mataró i dues de Girona), tres del Priorat i tres més del Maresme. La diversitat territorial i de volum de població és escassa. En el gràfic I hem representat els quatre fragments de sèries, convertits en números índex. Les sèries del segle XVI estan construïdes sobre la base I590-I599=I00 i després s'han relligat amb les del segle XVII. Es tractava de veure si els tres fragments de sèries del segle XVI se superposaven i seguien la mateixa tendència. El resultat no pot ser millor: les tres segueixen la mateixa trajectòria, potser amb l'excepció de la que comença el I5IO, que sembla que està per sobre de quan tenim una mostra més gran. La valoració és que podem acceptar l'evolució de les sèries a partir de I550, i potser hem de tenir una mica de precaució en les que comencen el I5IO. En aquesta data avaluaríem potser la població una mica a l'alça.

El gràfic es complementa amb el quadre 2 que recull, en números índex, l'evolució dels baptismes al llarg dels dos segles i una proposta d'evolució de la població de Catalunya al llarg d'aquest període. A partir d'aquests resultats podem definir les etapes següents: 
I. Els baptismes i la població es mostren estancats pràcticament fins el I540, després de travessar un lleuger retrocés a la dècada I520-I529.

2. A continuació s'inicia un vigorós creixement de la població que serà continuat fins el I630. En aquests 90 anys, els naixements es van incrementar un $85 \%$. El període de creixement més intens se situa entre I540 i I579, en què els baptismes creixen gairebé el $60 \%$ i al voltant de dos dígits sobre la dècada anterior, destacant la dècada I550-I559 amb un $15, \mathrm{I} \%$. La dècada de I580-I589 veu aturar el creixement (disminueix lleugerament sobre la dècada anterior) per continuar creixent a un ritme una mica inferior al de la primera etapa. ${ }^{18}$ L'explicació clàssica i fonamental d'aquest creixement s'ha de relacionar amb la immigració francesa que va produir-se just durant aquest període. ${ }^{19}$

3. A partir de 1630 el creixement dels baptismes s'atura i entra en una clara recessió que dura fins el I660. Entre I650 i I660 s'assoleix el mínim. Els naixements se situen al nivell de 1590 en aquesta dècada.

I8. Relacionat amb la dura crisi de mortalitat de l’any I589, Simón, «La població catalana a l'Ėpoca Moderna».

19. Hi ha innombrables i excellents treballs sobre la immigració francesa dels segles XVI i XVII. No ens toca recollir tota la bibliografia. Hem de destacar el treball pioner de Jordi Nadal i Emili Giralt, La population catalane de 1553 a I7I7. L'immigration française et les autres facteurs de son developpement, SEVPEN, París, I960 que va cridar l'atenció sobre aquest fenomen i les síntesis realitzades per Antoni Simón, «El redreçament demogràfic del llarg segle XvI. El paper de la immigració occitana», a Història de Catalunya, L'Esfera dels Llibres, Barcelona, 2004, pp. 356-37I; Antoni SImón, «El creixement poblacional català del segle Xvi i la immigració francesa. Aspectes demogràfics i socials", a Felipe II y el Mediterráneo, vol. I. Los recursos humanos y materiales, Sociedad Estatal para la Conmemoración de los Centenarios de Felipe II y Carlos V, Madrid, 1999, pp. 79-98. Els darrers anys cal destacar la tesi realitzada a partir de les esposalles del bisbat de Barcelona que, al mateix temps, dibuixa un bon estat de la qüestió: Miquel AmenguaL, «La immigració francesa a l'àrea de Barcelona a l'època moderna (segles XVI, XVI i XVII)", tesi doctoral, Universitat Autònoma de Barcelona, 20I8; Miquel Amengual i Joana Maria Pujadas-Mora, "Orígens i destins de la immigració francesa a l'àrea de Barcelona (I48I-I643). Aportacions a partir de la Barcelona Historical Marriage Database», Manuscrits. Revista d'història moderna, 34 (2017), pp. 35-6I. Una síntesi recent: Valentí GuAL i Raimon MADÉu, La immigració occitana a la Catalunya Moderna, Dalmau Editors, Barcelona, 202I. 
GrÀFIC I. Evolució dels baptismes a Catalunya (I510-1700)

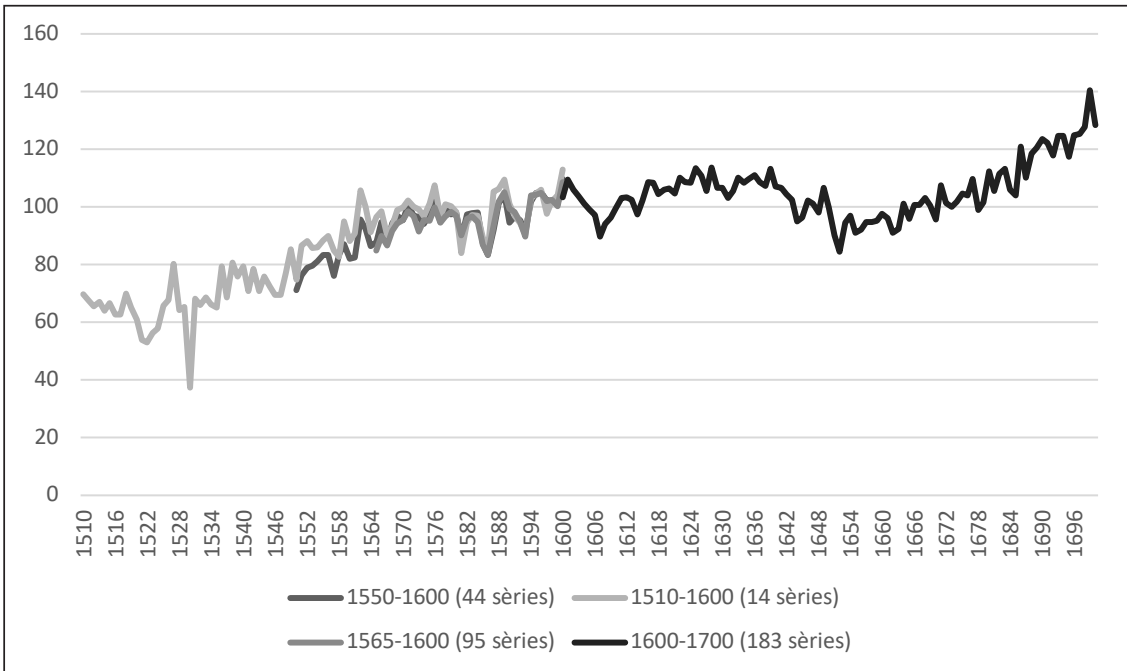

Per entendre la davallada són clau els estralls de la Guerra dels Segadors i la pesta bubònica, que circulà per Catalunya entre 1650 i $1655 .{ }^{\circ \circ}$ Una alta mortalitat i uns esdeveniments que desestructuren la població.

4. Cap el I680 s'assoleix de nou el nivell de naixements de I600 i, a partir d'aquí, s'inicia una etapa de recuperació, de tal manera que a finals del segle XvII els naixements havien crescut un $25 \%$. El balanç del segle és, doncs, modest i s'assoleix gràcies al dinamisme dels darrers vint anys.

En síntesi, des de començaments del segle Xvi i fins a finals del segle XVII la població es va multiplicar per 2,I. Ara bé, aquest creixement es produeix al segle XVI (guanys del $63 \%$ en tot el segle), mentre que el XVII presenta un creixement molt moderat, amb un retrocés a mitjans de segle i l'inici d'una vigorosa recuperació els darrers vint anys. (quadre 2)

20. Hi ha també moltes recerques sobre la pesta bubònica de 1650-1655. Vegeu sobretot Manuel Clemente i Manuel Camps Surroca, La pesta de meitats del segle XVII a Catalunya, Seminari Pere Mata, Lleida, I985; Narcís Castells, "La peste a mediados del siglo XviI en Catalunya", Pre-actas del I Congreso Hispano Luso Italiano de Demografía Histórica, Barcelona, 1987, pp. I04-II2. 
QUADRE 2. Evolució dels naixements en números índex i de la població de Catalunya per dècades

\begin{tabular}{|c|c|c|c|c|c|}
\hline & $\begin{array}{c}1510- \\
1519=100\end{array}$ & $\begin{array}{c}1600- \\
1609=100\end{array}$ & $\begin{array}{c}\text { Índex } \\
\text { encadenat }\end{array}$ & $\begin{array}{l}\text { Població de } \\
\text { Catalunya (I) }\end{array}$ & Any \\
\hline I5IO-I5I9 & IOO,O & 58,6 & IOO,O & $317.78 \mathrm{I}$ & 1520 \\
\hline $1520-1529$ & 94,6 & 55,4 & 94,6 & 300.478 & 1530 \\
\hline I53O-I539 & $\mathrm{IO} 2,3$ & 59,9 & IO8,I & 324.963 & I540 \\
\hline I54O-I549 & $\mathrm{II} 3,3$ & 66,4 & IIO,8 & 360.090 & 1550 \\
\hline I55O-I559 & $\mathrm{I} 3 \mathrm{O}, 4$ & 76,4 & II $5, \mathrm{I}$ & $4 \mathrm{I} 4.4 \mathrm{II}$ & 1560 \\
\hline $1560-1569$ & 146,7 & 83,4 & IO9,I & 466.208 & 1570 \\
\hline I57O-I 579 & 156,9 & 91,9 & IIO, 2 & 498.442 & 1580 \\
\hline I58O-I589 & $\mathrm{I} 54, \mathrm{O}$ & 90,2 & 98,2 & 489.364 & 1590 \\
\hline I590-I599 & 163,0 & 95,5 & 105,9 & 517.997 & 1600 \\
\hline I600-I609 & I70,6 & IOO,O & IO4,7 & 542.292 & I6IO \\
\hline I6I0-1619 & 176,6 & 103,5 & 103,5 & 561.272 & 1620 \\
\hline I620-I629 & 185,7 & IO8,8 & 105,2 & 590.230 & 1630 \\
\hline I630-I639 & I85,0 & $\mathrm{IO} 8,4$ & 99,6 & 587.790 & I640 \\
\hline I640-I649 & $\mathrm{I} 74, \mathrm{O}$ & $\mathrm{IO} 2, \mathrm{O}$ & $94, \mathrm{I}$ & 552.975 & 1650 \\
\hline I650-I659 & 159,4 & 93,4 & $9 \mathrm{I}, 6$ & 506.446 & 1660 \\
\hline I660-I669 & 167,0 & 97,9 & $\mathrm{IO}_{4}, 8$ & 530.795 & I670 \\
\hline I670-I679 & 174,9 & $\mathrm{IO} 2,5$ & IO4,7 & 555.849 & 1680 \\
\hline I680-I689 & I9I, 6 & $\mathrm{II} 2,3$ & 109,5 & 608.722 & 1690 \\
\hline I690-I699 & $2 \mathrm{I} 3, \mathrm{O}$ & $\mathrm{I} 24,8$ & III, 2 & 676.780 & 1700 \\
\hline
\end{tabular}

(I) S'agafa de base la població estimada el 1717 (696.792 Hab.)

Font: Elaboració pròpia a partir de les sèries parroquials esmentades en l'annex.

Podem determinar quants eren els habitants de Catalunya? En realitat tenim només dades de naixements, i convertir-les en habitants és forçar les dades, però davant l'escassetat de respostes ho hem fet així. Hem partit de la població que hi havia a Catalunya el I7I7 en la suposició d'una natalitat del 40 \%o (696.000 habitants) a partir de la revisió que hem proposat d'aquesta xifra en altres treballs. Així mateix hem construït un número índex de naixements i, per tant, hem deduït la població de Catalunya segons els naixements suposant una taxa bruta 
de natalitat del $40 \%$. Els resultats es troben a les columnes finals del quadre 2.

Les xifres de població que aportem són més altes que les que proporciona Jordi Nadal. ${ }^{2 r}$ Segons les nostres dades, Catalunya podria haver partit d'una població de 317.000 habitants a començaments del segle XVI i haver-se mantingut estancada fins el I540 (324.000), moment que hauria iniciat un ràpid creixement que li hauria permès superar el mig milió d'habitants a començaments del segle XVII (5I8.00o). El creixement va continuar fins a situar-se en els 590.000 habitants cap el I630. En una mica més d'un segle la població es devia incrementar un 85,7\%, una mica menys del que havia passat al segle XviII. L'arribada de francesos hauria estat determinant en aquest procés d'expansió. La crisi de mitjan segle Xvir va afectar de manera important la població, que es va reduir fins a 506.00o habitants, per sobre, això sí, del mig milió d'habitants. ${ }^{22}$ Catalunya estava més poblada del que hom podia pensar, per sobre dels 357.000 habitants que Nadal donava per a l'any I650. ${ }^{23}$

Del 1660 enllà la població va iniciar un procés de recuperació que es va accelerar a partir de I680, iniciant una trajectòria que continuà al segle XVIII, només aturada per la Guerra de Successió. El segle XVII es tancà amb 676.000 habitants. El I7I7 ratllava els 700.000. Totes aquestes xifres estan calculades suposant una natalitat del 40 per mil. És possible que fos més alta i aleshores la població estaria per sota d'aquestes xifres. Tot i així pensem que tant els ritmes com les xifres absolutes s'acosten a la realitat, avalades per la important quantitat de dades utilitzades.

De fet, el nostre objectiu és centrar-nos en l'evolució demogràfica del segle XVII. El mateix quadre 2 permet veure com el segle XviI presenta una evolució pràcticament plana dels baptismes. El I629 amb

2I. Jordi Nadal, Bautismos, desposorios y entierros. Estudios de historia demográfica, Ariel, Barcelona, 1992.

22. Aquesta xifra coincideix amb la que dona Altamira a la Historia de Cataluña (519.800). Citat per Pierre VILaR, Catalunya dins l'Espanya Moderna. Recerques sobre els fonaments econòmics de les estructures nacionals (Barcelona: 62, I964), II, 349. La que dona per a 1553 (326.970) és més baixa que la que donem nosaltres.

23. NADAL, Bautismos, desposorios y entierros. Estudios de historia demográfica, p. 96. 
prou feines eren el ıo \% més nombrosos que el ı600, i la davallada de mitjan segle va portar a una disminució del $7 \%$ respecte al punt de partida. Va ser la recuperació que s'inicià primer lentament i després s'accelerà a partir de I680 que va fer que el segle acabés amb uns guanys del $25 \%$, molt lluny dels increments dels segles XVI i XVIII.

Però, com es va repartir, aquest creixement? El quadre 3 recull l'evolució dels baptismes per regions, ${ }^{24}$ cosa que ens permet copsar la tendència dels ritmes al llarg de Catalunya i és al que podem aspirar amb les dades de què disposem. No ens hem atrevit a fer-ho per comarques, ja que les mostres que tenim no són bones en molts casos i correm el risc de distorsionar els resultats. (quadre 3)

L'evolució dels naixements no va seguir la mateixa dinàmica a tot Catalunya. Tot sembla indicar que el creixement es va concentrar fonamentalment a les zones pirinenques i a les comarques de Barcelona. A la regió 9, per exemple, que agafa les comarques pirinenques del Pallars i l'Alt Urgell, els naixements es van incrementar el $57 \%$ al llarg del XVII i la crisi de mitjan segle va passar de llarg (tot i que en aquest cas la mostra és petita). El mateix va passar a les comarques del Ripollès i l'Osona, on tampoc va haver-hi crisi i el segle Xvir va acabar amb un creixement del $85 \%$. Són dades que ens indiquen el vigor del creixement demogràfic en aquestes comarques del país, que es devia veure complementat per un creixement del $49 \%$ a la regió i (Vallès Occidental i Oriental, Maresme i Baix Llobregat) on la crisi també va passar de llarg. El gràfic 2 recull aquestes evolucions positives per damunt de la mitjana de Catalunya. ${ }^{25}$

En canvi, van haver-hi zones molt perjudicades. El gràfic 3 recull l'evolució dels naixements de la regió 3 (comarques tarragonines), en què la crisi de mitjan segle XVII va reduir la població un I7 \% respecte de començaments de segle i al final de la centúria només s'havia recuperat un 7 \%; la regió 4, també a la província de Tarragona (Baix Camp,

24. Utilitzem la divisió per regions que va fer la Generalitat republicana. Són àmbits que s'ajusten més a la realitat diversa de Catalunya que no pas les províncies.

25. En el gràfic 2 no hi ha representada la regió 9 , simplement perquè només tenim un $4,9 \%$ de la població i amb un nombre de parròquies poc significatiu. 
QUADre 3. L'evolució dels baptismes a Catalunya per regions a partir de I83 sèries parroquials (I600-I699) (I690-I699=I00)

\begin{tabular}{|l|c|c|c|c|c|c|c|c|c|c|c|}
\hline & $\begin{array}{c}\text { I600- } \\
\text { I609 }\end{array}$ & $\begin{array}{c}\text { I6I0- } \\
\text { I6I9 }\end{array}$ & $\begin{array}{c}\text { I620- } \\
\text { I629 }\end{array}$ & $\begin{array}{c}\text { I630- } \\
\text { I639 }\end{array}$ & $\begin{array}{c}\text { I640- } \\
\text { I649 }\end{array}$ & $\begin{array}{c}\text { I650- } \\
\text { I659 }\end{array}$ & $\begin{array}{c}\text { I660- } \\
\text { I669 }\end{array}$ & $\begin{array}{c}\text { I670- } \\
\text { I679 }\end{array}$ & $\begin{array}{c}\text { I680- } \\
\text { I689 }\end{array}$ & $\begin{array}{c}\text { I690- } \\
\text { I699 }\end{array}$ & $\begin{array}{c}\% \\
\text { Població }\end{array}$ \\
\hline regió I & I00 & I07 & II3 & I20 & I23 & II4 & II6 & I20 & I3I & I49 & $3 \mathrm{I}, 6$ \\
\hline regió 2 & I00 & I02 & II0 & I06 & III & 92 & I00 & I07 & II4 & I22 & 27 \\
\hline regió 3 & I00 & I00 & I04 & I00 & 86 & 83 & 84 & 85 & 92 & I07 & 46,7 \\
\hline regió 4 & I00 & I02 & I04 & 96 & 80 & 75 & 80 & 84 & 95 & IIO & 42,0 \\
\hline regió 5 & I00 & 89 & 95 & 93 & 66 & 63 & 72 & 66 & 82 & I00 & 40,6 \\
\hline regió 6 & I00 & II8 & I27 & I37 & I36 & I32 & I49 & I59 & I78 & I85 & 20 \\
\hline regió 7 & I00 & I0I & I05 & I04 & I02 & I02 & 97 & I08 & II5 & II9 & I8 \\
\hline regió 8 & I00 & I08 & I23 & I24 & I04 & 88 & 94 & I03 & II4 & I23 & I7,3 \\
\hline regió 9 & I00 & I44 & I06 & I48 & I36 & I26 & I30 & I30 & I45 & I57 & 4,9 \\
\hline Catalunya & I00 & I04 & I09 & I08 & I02 & 93 & 98 & I03 & II2 & I25 & $27, I$ \\
\hline
\end{tabular}

Font: Elaboració pròpia a partir de les sèries parroquials esmentades a l'annex.

Gràfic 2. Evolució dels naixements de les regions de Catalunya que creixen més (I600-I700

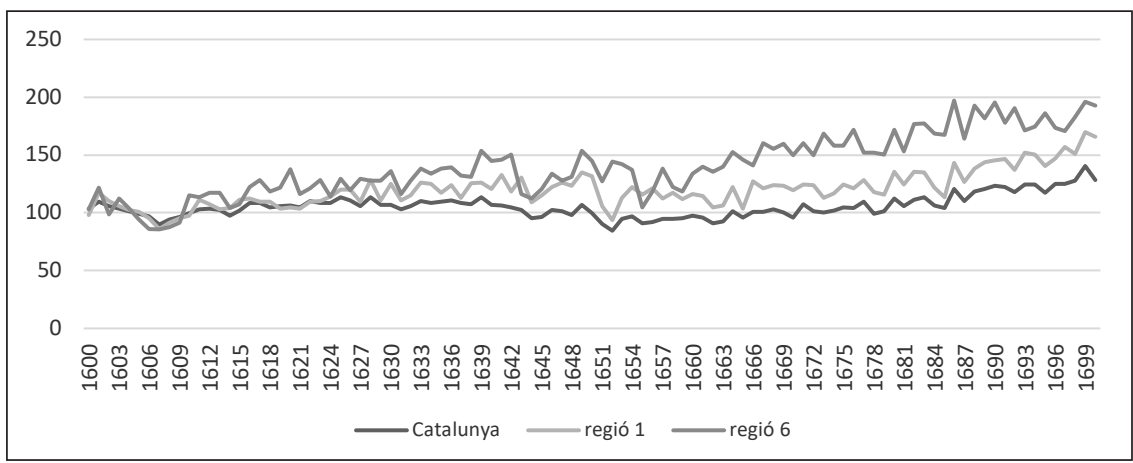


Conca de Barberà i Priorat), en què els naixements van caure un $25 \%$ i al final de segle s'havia incrementat només un Io \% i, finalment, les terres de l'Ebre, que es on es va produir la crisi més profunda (van caure un $37 \%$ ) i a finals de segle la població era la mateixa que al començament. ${ }^{26}$ Tot sembla indicar, doncs, que la crisi demogràfica més important es va produir a les comarques de Tarragona i a les terres de l'Ebre.

Gràfic 3. Evolució de les regions de Catalunya amb creixement més negatiu (I600-1700)

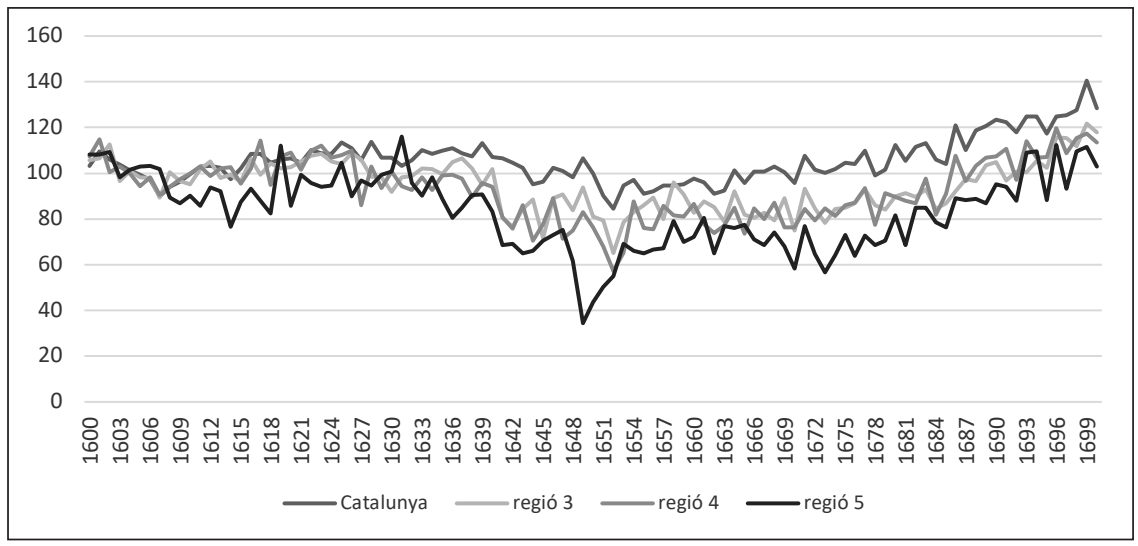

Finalment, tenim les zones en què la població va seguir més o menys la mitjana de Catalunya (gràfic 4 ). Trobem les comarques de Girona en què la crisi va provocar una caiguda del $8 \%$ i al final s'arribà a un creixement del $22 \%$; la regió 7 , que agafa les comarques centrals on la crisi va ser moderada i el creixement final va ser del I9 \%; i, finalment, les terres de Lleida, on la crisi va ser important (reducció dels naixements del I2 \%), però al final de segle la població s'havia recuperat el $23 \%$.

26. Vilar fa referència al profund despoblament que es produí a les terres de Lleida i a les terres de l'Ebre afectades per l'expulsió dels moriscos (Pierre Vilar, Catalunya dins l'Espanya Moderna. Recerques sobre els fonaments econòmics de les estructures nacionals, II, p. 348). Les nostres dades no reflecteixen aquest despoblament global a les comarques de Lleida. Caldria, però, tenir més sèries reconstruïdes. 
GrÀric 4. Evolució de les regions que creixen com la mitjana de Catalunya (I600-1700)

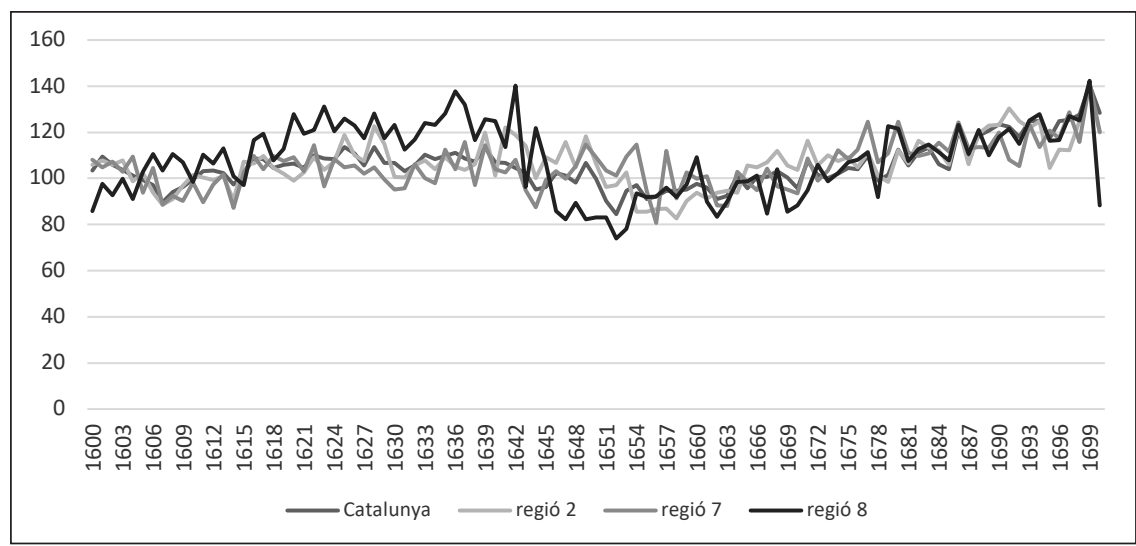

En aquest punt ja podem dibuixar una geografia de l'evolució de Catalunya al segle XVII: un important creixement a les comarques de muntanya i a la plana de Vic, una davallada i escassa recuperació a les comarques tarragonines i terres de l'Ebre i una crisi més moderada i un creixement també moderat a la resta del país.

Volem anar una mica més enllà. Aquesta evolució que hem descrit i que va tenir una evolució diferent segons els territoris, va ser homogènia quant a la mida de la població de les parròquies? Els pobles petits i les ciutats més grans, es van comportar igual? Per fer aquesta anàlisi hem agrupat les sèries demogràfiques en funció dels habitants que les parròquies tenien el $17 \mathrm{I} 7 \mathrm{amb}$ una natalitat suposada del $40 \%$ i els hem agrupat en diferents categories, com es recull en el quadre 4 i el gràfic $5 .{ }^{27}$

27. En aquests quadres no figura la sèrie de la parròquia de Sant Just i Pastor de Barcelona ja que no equival a la població de Barcelona, ni tampoc les de Tàrrega, Anglesola, Verdú i Vilagrassa, de les quals no tenim les dades desagregades i per tant no podem saber què aporta cada població. 
QUADRE 4. L'evolució de la població segons la grandària de la població el I7I7 a partir de 178 sèries parroquials (I600-I699) (I690-I699=I00)

\begin{tabular}{|l|c|c|c|c|c|c|c|c|c|c|c|}
\hline habitants & $\begin{array}{c}\text { I600- } \\
\text { I609 }\end{array}$ & $\begin{array}{c}\text { I6I0- } \\
\text { I6I9 }\end{array}$ & $\begin{array}{c}\text { I620- } \\
\text { I629 }\end{array}$ & $\begin{array}{c}\text { I630- } \\
\text { I639 }\end{array}$ & $\begin{array}{c}\text { I640- } \\
\text { I649 }\end{array}$ & $\begin{array}{c}\text { I650- } \\
\text { I659 }\end{array}$ & $\begin{array}{c}\text { I660- } \\
\text { I669 }\end{array}$ & $\begin{array}{c}\text { I670- } \\
\text { I679 }\end{array}$ & $\begin{array}{c}\text { I680- } \\
\text { I689 }\end{array}$ & $\begin{array}{c}\text { I690- } \\
\text { I699 }\end{array}$ & $\begin{array}{c}\text { \% Població } \\
\text { estudiada }\end{array}$ \\
\hline fins a 500 & I00 & I03 & I08 & I04 & I06 & I0I & 99 & I02 & IIO & I24,2 & II,7 \\
\hline 500 a I000 & I00 & I04 & I09 & II5 & IIO & I06 & II2 & I20 & I26 & I35,0 & I2,8 \\
\hline I000 a 2000 & I00 & I05 & III & II2 & II2 & IOI & IIO & II7 & I28 & I39,2 & 26 \\
\hline 2000 a 4000 & I00 & I08 & II3 & IIO & I07 & I05 & I09 & III & II9 & I29,4 & I9,7 \\
\hline 4000 a 8000 & I00 & I00 & I05 & I05 & 85 & 7 I & 75 & 79 & 91 & I07,I & 29,3 \\
\hline Catalunya & I00 & I03 & I09 & I07 & IOI & 92 & 96 & I00 & IIO & I23,4 & 26,2 \\
\hline
\end{tabular}

Font: Elaboració pròpia a partir de les sèries parroquials esmentades a l'annex.

GrÀFIC 5. Evolució de la població segons els habitants dels pobles $(\mathrm{I} 60 \mathrm{I}-\mathrm{I} 609=\mathrm{IOO})$

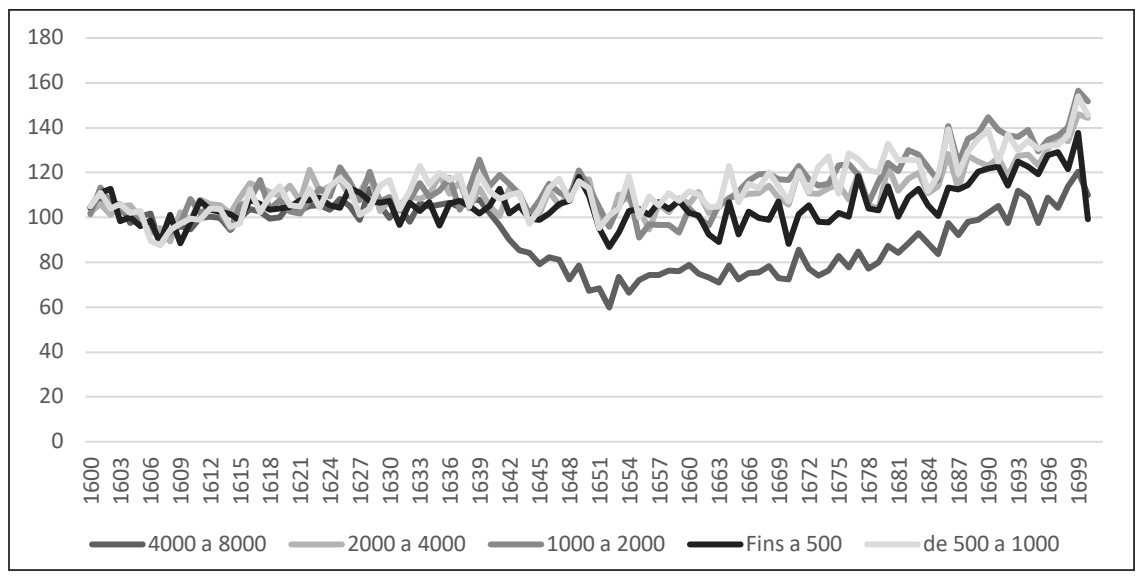

És cert que el total de població controlada de cada tipus de parròquia és relativament baixa. Les ciutats més grans signifiquen el 29,3\% del total de població estudiada i els pobles més petits signifiquen només l'II,7\% del total de baptismes observats. Tot i així els resultats són fins a cert punt sorprenents. Totes les parròquies, al marge de la grandària de la població, passen la crisi de mitjan segle XvII i a partir de I640 els bap- 
tismes es redueixen a tot arreu, fet que continua fins el 1659, abans de començar la recuperació. Però hi ha un element molt significatiu, per sota dels 4.000 habitants els naixements no baixen mai del nivell de I600 i la caiguda és modesta (entre 5 i Io punts com a molt); en canvi, les ciutats més grans pateixen una davallada sense precedents. El I630 ja van començar a baixar respecte al període anterior, però el 1659 els baptismes s'havien reduït el 29 \% i la recuperació va ser extraordinàriament lenta, de tal manera que el 1689 encara no s'havia assolit el nivell de 1600 i a finals del segle Xvir la població d'aquestes ciutats només s'havia incrementat el 7,I \% respecte a I600, mentre que a Catalunya ho feia el 23,4\%.

De fet, el creixement de la població és el resultat de l'evolució demogràfica dels pobles petits. El I699, els naixements havien crescut el $24,2 \%$ en els pobles per sota de 500 habitants, el $35 \%$ els de 500 a I.000 i el 39,2 \% els de I.000 a 2.000. La crisi va afectar aquestes parròquies, però fou relativament lleu i el creixement, sense ser extraordinari, va quedar molt per damunt de la mitjana. La crisi demogràfica del XVII va ser, de fet, una crisi de les poblacions més grans que van veure com s'enfonsaven els naixements durant la Guerra dels Segadors i la pesta bubònica, i a finals de segle amb prou feines havien recuperat la població del començament de la centúria.

La caiguda de baptismes recull una caiguda de la població o el desballestament social provocat per la guerra i la pesta? El que tarden a recuperar-se ens fa pensar que la caiguda afectava també la reducció de la població.

\section{L'evolució de la mortalitat al segle XVII}

Com explicar l'estancament de la població de Catalunya durant bona part del XVII? Un argument important és la reducció a partir de i6 Io de l'aportació migratòria occitana, però això justifica una reducció del creixement i no un estancament, que és el que hem vist que es va produir. Per entendre aquest estancament hem d'analitzar què va passar amb la fecunditat i, sobretot, amb la mortalitat. 
Utilitzarem la mateixa metodologia: l'agregació de sèries de defuncions de parròquies del segle XVII. En total n'hem aplegat 78, que suposen el I3 \% de la població catalana rectificada de I7I7 (trobareu el llistat de les poblacions afectades en l'annex adjunt). Les sèries de mortalitat presenten moltes més dificultats i són de menys qualitat que les de baptismes. A més dels problemes derivats de la particularitat de cada parròquia, el principal problema és que o bé no recullen els albats o bé ho fan de manera incompleta, o bé uns anys es recullen $\mathrm{i}$ d'altres no. Davant d'aquesta diversitat, no hem pogut aprofitar les sèries de mortalitat de què desconeixem com estan inscrits els albats, ja que no es poden corregir de cap manera. Normalment s'estima que els albats constitueixen el $50 \%$ de la mortalitat general. De fet, en els treballs que hem realitzat pel que fa al segle Xvin hem donat per bones les sèries en què els albats assoleixen aquesta quantitat. Al segle XVII, excepte en algun cas i alguna dècada d'alguna sèrie, aquest supòsit no es compleix. ${ }^{28}$

Amb aquest panorama caldria desestimar totes les sèries de mortalitat. Per aprofitar-les i poder fer una valoració de l'evolució de la mortalitat amb les precaucions que calgui, hem utilitzat les sèries de defuncions d'adults, que donem per bones, i les hem multiplicat per dos, a partir del supòsit que els albats significaven el $50 \%$ de mitjana de la sèrie. Hem deixat de banda tota la informació d'albats, ja que gairebé sempre està per sota de la mitjana. ${ }^{29} \mathrm{El}$ mètode té l'avantatge que

28. Les sèries que podríem donar per bones seguint aquest criteri són una mínima part. Les dues sèries de mortalitat de Barcelona (parròquia de Santa Maria del Pi, de la qual no tenim naixements o la de Sant Just i Pastor) (Jordi Andreu Sugranyes i Antoni Simón Tarrés, "Evolució demogràfica (segles XVI i XVII)», a Història de Barcelona. Barcelona dins la Catalunya Moderna (segles XVI-XVII), Fundació Enciclopèdia Catalana, Barcelona, I992, pp. I24-I38); les de Girona del segle XVI (Ramon ALBERCH i Antoni Simón TARrés, "L'evolució demogràfica de Girona en els segles XVI i XVII a través dels registres parroquials», Estudi General, I982, pp. II-3I), la de Sant Celoni i Sant Feliu de Codines.

29. Això ens ha obligat a no considerar les sèries de defuncions del segle XvII que no separaven adults d'albats. No les podíem multiplicar per dos per obtenir la mortalitat total perquè hi havia albats barrejats i això ens hauria distorsionat els resultats, 
s'acosta a l'evolució de la mortalitat global, però es tracten adults i albats per igual, la qual cosa pot ser vàlida en el càlcul global, però no any $\mathrm{a}$ any, en què a vegades hi ha anys amb molta mortalitat adulta $\mathrm{i}$ anys amb molt poca, i això dificulta la caracterització de la mortalitat catastròfica.

Gràfic 6. Evolució dels baptismes i defuncions en 78 parròquies de Catalunya (I600-1699)

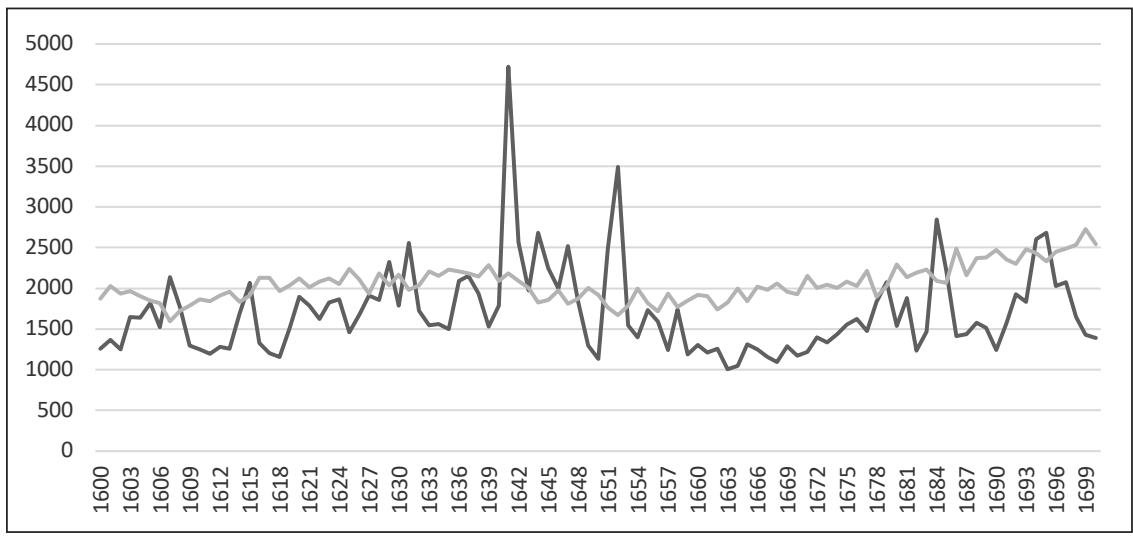

El gràfic 6 mostra l'evolució de la mortalitat acumulada de 78 parròquies. D'entrada, hi destaquen les puntes de mortalitat que apareixen sovint amb més o menys intensitat. A la primera meitat del segle, baptismes i defuncions van paral.lels amb contínues sotraguejades de la mortalitat tot i que modestes, i arriben a la crisi de mitjan segle XVII en què les puntes de mortalitat es disparen especialment el I64I i el I652, amb altres puntes més modestes entre aquests anys. La Guerra dels Segadors, especialment, i la pesta bubònica tenen un efecte devastador sobre la població. Després, tal vegada perquè ja molta gent havia mort, la mortalitat viu un període de tranquil.litat fins a arribar a altres pu-

ni podíem donar-les per bones perquè sabem que hi ha ocultació d'albats. Això mateix ha reduït la nostra mostra de treball. 
ntes a finals del segle Xvir. Gairebé podem avançar que l'elevada mortalitat catastròfica va ser segurament la causa que explica l'aturada del creixement de la població catalana al segle XviI.

\section{GRÀFIC 7. Creixement vegetatiu en 78 parròquies} de Catalunya (1600-1699)

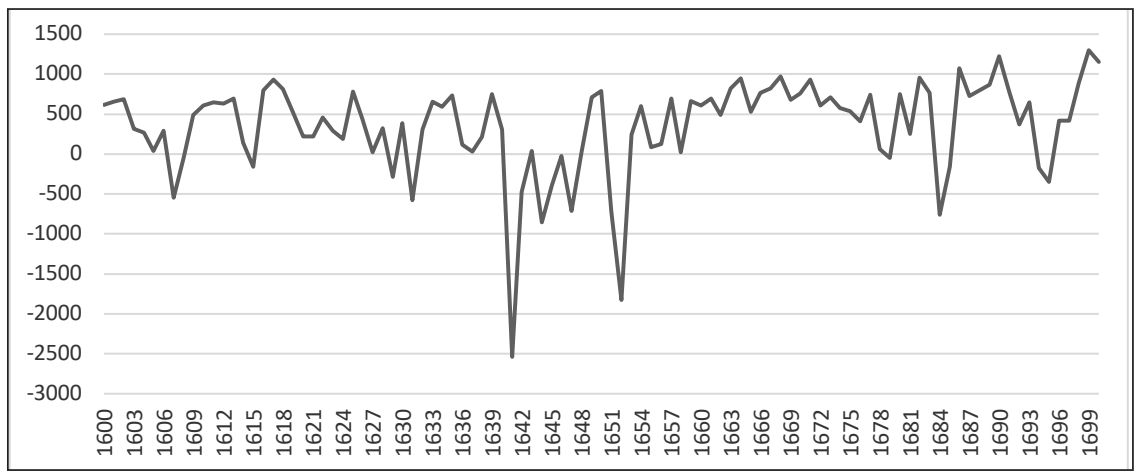

El gràfic 7 i el quadre 5 se centren més en el creixement vegetatiu que van tenir aquestes parròquies, a fi de comprovar si l'evolució de la mortalitat va influir en l'evolució de la població. Pels problemes i les manipulacions de les fonts, cal prendre els resultats amb precaució. Ens hi podem acostar de maneres diferents. La relació defuncions/baptismes està per sobre del $90 \%$ durant la primera meitat de segle, es desborda fins a I3I la dècada de I64I-I650 i es manté molt alta fins el I660. Al llarg del segle XVIII, aquest percentatge va estar entre el $70 \mathrm{i}$ $80 \%$, que és el que permet un creixement vegetatiu important. ${ }^{30}$ En

30. Alguns estudis sobre l'Espanya interior mostren per al segle XviII aquesta elevada mortalitat: Enrique Llopis, José Ubaldo Bernardos, i Angel Luís Velasco, "¿Pasó de largo por la España interior la primera fase de la transición demográfica? La mortalidad en Âvila y Guadalajara (1700-1895)", Investigaciones de Historia Económica, II (20I5), pp. 69-79; Enrique Llopis i Ángel Luis Velasco, «Mortalidad y crecimiento vegetativo en la provincia de Guadalajara, 1700-1865", Sociedad Española de Historia Agraria, núm. DT-SEHA n. I2-O2 (2OI2); Vanesa ABARCA et al., «El descenso de la mortalidad en la España interior: Albacete y Ciudad Real, I700-I895", América 
aquesta etapa, doncs, el creixement va ser modest la primera part del segle i clarament negatiu als anys centrals. El gràfic 7 mostra la combinació d'anys positius amb una colla d'anys de crisi de mortalitat i la profunda gravetat de les crisis de mortalitat de mitjan segle XviI, que analitzarem més endavant. (quadre 5)

QuADre 5. Baptismes, defuncions i creixement vegetatiu a Catalunya (I600-I700) en 78 parròquies

\begin{tabular}{|c|c|c|c|c|c|c|}
\hline & Baptismes & $\begin{array}{c}160 \mathrm{I}- \\
\mathrm{I} 6 \mathrm{IO}=\mathrm{I00}\end{array}$ & Defuncions & $\begin{array}{c}\mathrm{I} 60 \mathrm{I}- \\
\mathrm{I} 6 \mathrm{I0}=\mathrm{I00}\end{array}$ & $\begin{array}{c}\text { Creixement } \\
\text { vegetatiu }\end{array}$ & $\begin{array}{c}\text { Defuncions/ } \\
\text { baptismes }\end{array}$ \\
\hline I6OI-I6IO & 23.665 & IOO,O & 21.456 & IOO,O & $2.208,5$ & 90,7 \\
\hline I6II-I620 & 25.178 & IO6,4 & $20.8 \mathrm{II}$ & 97,0 & $4.367,5$ & 82,7 \\
\hline I62I-I630 & 26.319 & III, 2 & 24.923 & $\mathrm{II} 6,2$ & I.395,7 & 94,7 \\
\hline I63I-I640 & 26.662 & $\mathrm{II} 2,7$ & 24.358 & 113,5 & $2.304,0$ & $9 \mathrm{I}, 4$ \\
\hline I64I-I650 & $24.5 \mathrm{I} 4$ & 103,6 & 32.253 & 150,3 & $-7.739,0$ & I3I, 6 \\
\hline $165 \mathrm{I}-\mathrm{I} 660$ & 22.955 & 97,0 & $22.42 \mathrm{I}$ & 104,5 & 534,0 & 97,7 \\
\hline $166 \mathrm{I}-\mathrm{I} 670$ & 23.850 & IOO, 8 & 15.578 & 72,6 & $8.272,4$ & 65,3 \\
\hline I67I-I680 & 25.559 & IO8,0 & 21.282 & 99,2 & $4.276,8$ & 83,3 \\
\hline I68I-I690 & 27.532 & II 6,3 & 23.276 & 108,5 & $4.256,0$ & 84,5 \\
\hline I69I-I700 & 30.679 & $\mathrm{I} 29,6$ & 25.528 & II9,O & $5.150,7$ & 83,2 \\
\hline
\end{tabular}

La segona meitat de segle la situació canvia. Entre I66I i i670 la relació baptismes/defuncions relació baixa fins el 65,3 \% i el creixement vegetatiu es dispara. L'elevada mortalitat del període anterior ha eliminat moltes persones que ara ja no hi són i això afecta la mortalitat general, però no sembla que la fecunditat es recuperi. La relació entre defuncions i baptismes continua alta, però és inferior a la de la primera part del segle $(83 / 84 \%)$, i això permet un creixement vegetatiu més sòlid que explica la recuperació de la població a partir de I670/I680, com hem vist en l'evolució general.

Latina en la Historia Económica, 22 (2015), pp. I08-I44. Sobre aquesta relació a Catalunya, vegeu Ferrer-Alòs, «Una transició demogràfica primerenca. Sobre l'evolució demogràfica de Catalunya (segles XVIII-XIX)». 
Aquestes 78 parròquies, que signifiquen el I3 \% de la població catalana (un percentatge important però no del tot suficient) presenten un creixement vegetatiu de 25.000 individus. Segons l'evolució dels baptismes —amb el doble de població com a mostra_-, el creixement del segle XVII va ser de 158.000 individus; segons el creixement vegetatiu, amb una mostra menor $\mathrm{i}$ amb unes sèries de mortalitat més problemàtiques (adults multiplicats per dos), devia ser més alt (I90.000 persones). Si els baptismes acostumen a tenir una certa lògica en tant que és una variable que la gent controla, la mortalitat no. Els accidents demogràfics (pestes i guerres) tenen intensitats diferents entre pobles $\mathrm{i}$ comarques i poden alterar molt la corba de mortalitat. Per això ens quedem amb la primera xifra i la segona ens permet veure les etapes i tendències del creixement vegetatiu.

Hem de concloure, doncs, que l'alta mortalitat devia ser una de les explicacions de l'escàs creixement de la població durant el segle XVII. Les crisis de mortalitat van tenir un gran protagonisme.

\section{Un segle de constants i greus crisis de mortalitat}

No és l'objectiu d'aquest treball analitzar les crisis de mortalitat que van tenir lloc al segle XVII, però atès la importància de la mortalitat catastròfica volem aproximar-nos-hi. De fet, hi ha moltes recerques que s'han acostat a aquesta problemàtica ${ }^{3 \mathrm{I}}$ utilitzant mètodes que han

3I. Valentí Gual Vila, «Les crisis de mortalitat adulta a la Conca de Barberà. Cronologia, intensitat i abast geogràfic», Quaderns de Vilaniu, núm. 24 (1993), p. 55; Clara García-Moro et al., "Crisis de mortalidad en la población de Tortosa. - Siglos XVII a XX», Revista Española Antropologia Biológica, 2I (2000), pp. IOI-IO9; Julie MARFANY, "Las crisis de mortalidad en una comunidad catalana, Igualada, I680-I8I9", Revista de Demografía Histórica, XXIII, 2 (2005), pp. I3-42; Miquel Planas Roig, "Les crisis de mortalitat a l'Alt Empordà», Plecs d'Història Local, 4 (I986), pp. 50-53; Manuel Camps Clemente i Manuel Camps Surroca, La pesta de meitats del segle XVII a Catalunya, Seminari Pere Mata, Lleida, I985; Margarita Gonzalvo-Cirac, Josep Fàbregas Roig i Judit Vidal-Bonavila, «Evolución demográfica del Camp de Tarragona (Cataluña, España) I570-1880: las grandes crisis de mortalidad", Población 
esdevingut clàssics. La majoria d'ells parteixen del concepte que la crisi de mortalitat és fonamentalment local i, per tant, analitzen les crisis parròquia a parròquia; només la coincidència entre parròquies permet afirmar que la crisi és o no general. El mètode presenta el problema que es magnifiquen crisis en parròquies més petites en què les oscilllacions de les defuncions són més aleatòries i imprevisibles, i redueix el pes en les poblacions més grans. Les intensitats es magnifiquen en unes i es minimitzen en altres.

D'altra banda, el fet de no utilitzar dades d'albats sinó de mortalitat adulta fa que, en realitat, mesurem les crisis de la mortalitat adulta que, segurament, no coincidien del tot amb la de mortalitat d'albats. I això matisa els resultats obtinguts perquè deixen de banda una part important de la mortalitat.

En aquest període, una crisi de mortalitat pot ser una tragèdia local aillada, però el que busquem és una manera de valorar fins a quin punt una crisi va ser generalitzada i el pes que va tenir realment sobre l'evolució demogràfica. Per això hem aplicat la metodologia que es troba explicada en una altra recerca ${ }^{32}$ i que, de manera sintètica, consisteix

y Salud en Mesoamérica I4, I, (2016), pp. 32-57; Antonio Moreno i Luis Navarro, "La crisis demográfica del siglo Xvil en el Baix Camp (I59I-I692)», en Primer Col.loqui d'Història del Camp de Tarragona, Conca de Barberà i Priorat, Instituto de Estudios Tarraconenses, Tarragona, 1979, pp. 49-65; Antoni Simón Tarrés, «Els anys I627-I632 i la crisi del segle XVII a Catalunya", Estudis d'Història Agrària, 1992, I57-80; Jaume Dantí Riu, Terra i població al Vallès Oriental. Ėpoca moderna, Ajuntament de Santa Eulàlia de Ronsana, I988; Alexandra CApdevila, «Les crisis de mortalitat al Maresme: Cronologia, intensitat i abast geogràfic», Trobada d'Entitats de Recerca Local i Comarcal del Maresme, 3 (2009), pp. 43-64; F. Xabier Gual i Carles Millàs, La població del Baix Llobregat a l'època dels Àustria, Fundació Salvador Vives Casajuana, Barcelona, 1999; Francesc Muñoz Pradas, "Creixement demogràfic. Mortalitat i nupcialitat al Penedès (s. XVII-XIX)», tesi de Doctorat, Universitat Autònoma de Barcelona, I990; José Luis Beltrán Moya, «Las grandes epidemias de peste en la Barcelona de los siglos xVI y XVII», tesi doctoral, Universitat Autònoma de Barcelona, 1993.

32. Llorenç Ferrer-Alòs, «Las crisis de mortalidad en Cataluña (I700-I860). Una reconstrucción a partir de las series parroquiales», Revista de Demografía Histórica, XXXIX, 3 (202I), pp. 83-I20. 
a agrupar les sèries per comarques, aplicar el mètode Del Panta-Livi Bacci $^{33}$ que mesura la desviació de la mortalitat respecte a un any central i considerar anys de crisi tots aquells anys en què la mortalitat se separa el $25 \%$ de la mitjana mòbil d'onze anys excloent l'any d'estudi, els dos anys amb la mortalitat més alta i els dos amb la més baixa. ${ }^{34}$ No utilitzem el topall del $50 \%$, ja que l'agrupació de sèries tendeix a difuminar les crisis locals que no sempre es produeixen el mateix any. ${ }^{35} \mathrm{Te}-$ nim sèries de 2I comarques, per tant treballarem sobre aquest total de comarques. ${ }^{36}$

El quadre 6 recull les principals crisis de mortalitat adulta que es van produir a Catalunya al segle XVII, tot i que no afectaren el territori de la mateixa manera. En primer lloc, recollim les comarques afectades, és a dir, les que un any o altre es van veure afectades i el percentatge sobre el total de comarques estudiades (2I). La mortalitat catastròfica obtinguda la dividim per 25 (que és el \% que ens ha servit per definir crisis de mortalitat). El resultat és la intensitat de la crisi, és a dir una intensitat de 4 és el resultat de dividir Ioo (el percentatge de desviació) per 25. Intensitat acumulada és la suma de les intensitats de totes les

33. M. Livi Bacci i L. Del Panta, "Chronology, intensity and diffusion of mortality in Italy, I600-1850", en H. Charbonneau i A. Larose, ed., Les grandes mortalités: étude méthodologique des crises demographiques du passé, Union International pour l'Etude Scientifique de la Population, 1979, pp. 69-88.

34. És el mateix mètode utilitzat per mesurar en unitats territorials més grans que el municipi a Espanya (Enrique Llopis i Vanesa AbarCA, «El retroceso de la mortalidad catastrófica y su papel en la moderación de la mortalidad general en la España interior en los siglos XVIII-XIX", en IV CLADHE, Simposio 26, Las grandes crisis y depresiones demográficas y económicas en Iberoamérica y la península Ibérica, 1300-2013, 2014.

35. El mètode presenta alguna dificultat perquè hi ha comarques de què només tenim una sèrie (Segrià, Alt Urgell) i aquell criteri no es compliria. Tot i que podríem haver personalitzat el càlcul segons la comarca, creiem que no distorsionem el càlcul general i l'objectiu de copsar les principals crisis demogràfiques del període.

36. No tenim cap sèrie de mortalitat que puguem utilitzar del Baix Empordà, Alt Empordà, Gironès, La Selva, Pla de l'Estany, Alt Camp, Ribera d'Ebre, Montsià, Baix Ebre, Bages, Garrigues, Noguera, Urgell, Pla d'Urgell, Pallars Jussà, Pallars Sobirà, Vall d'Aran i Alta Ribagorça. 
comarques afectades $\mathrm{i}$, finalment, la intensitat mitjana és el resultat de dividir la intensitat acumulada pel nombre de comarques. Destaquem nou grans crisis de mortalitat adulta amb una geografia i una intensitat variable.

QUADRE 6. Les crisis de mortalitat adulta a Catalunya en el segle XviI (a partir de 78 sèries)

\begin{tabular}{|l|c|c|c|c|}
\hline & Comarques & $\%$ comarques & $\begin{array}{c}\text { Intensitat } \\
\text { acumulada }\end{array}$ & $\begin{array}{c}\text { Intensitat } \\
\text { mitjana }\end{array}$ \\
\hline I606-I607 & I4 & 66,7 & $43, \mathrm{O}$ & $3, \mathrm{I}$ \\
\hline $\mathrm{I} 6 \mathrm{I} 4-\mathrm{I} 6 \mathrm{I} 5$ & $\mathrm{I} 8$ & 85,7 & $6 \mathrm{I}, 2$ & 3,4 \\
\hline $\mathrm{I} 629-\mathrm{I} 630$ & $\mathrm{I} 8$ & 85,7 & 87,4 & 4,9 \\
\hline $\mathrm{I} 64 \mathrm{I}-\mathrm{I} 644$ & $\mathrm{I} 8$ & 85,7 & $\mathrm{I} 65, \mathrm{I}$ & 9,2 \\
\hline $\mathrm{I} 647$ & $\mathrm{IO}$ & 47,6 & $28, \mathrm{I}$ & 2,8 \\
\hline $\mathrm{I} 650-\mathrm{I} 655$ & 20 & 95,2 & 202,3 & $\mathrm{IO}, \mathrm{I}$ \\
\hline $\mathrm{I} 678-\mathrm{I} 679$ & $\mathrm{I} 4$ & 66,7 & 38,7 & 2,8 \\
\hline $\mathrm{I} 684-\mathrm{I} 685$ & 20 & 95,2 & $8 \mathrm{I}, 2$ & $4, \mathrm{I}$ \\
\hline $\mathrm{I} 694-\mathrm{I} 695$ & $\mathrm{I} 7$ & $8 \mathrm{I}, \mathrm{O}$ & $6 \mathrm{I}, 8$ & 3,6 \\
\hline
\end{tabular}

I606-I607. Va afectar el 66,7\% de les comarques estudiades, amb una intensitat acumulada i mitjana modesta. Tot i així va ser intensa al Priorat $(6,2)$ i fou també important al Baix Penedès $(4,3)$ un any després.

I6I4-I6I5. Fou una crisis de mortalitat generalitzada: va afectar el 85,7\% de les comarques estudiades i, tot i la seva generalització, va ser més aviat lleu amb una intensitat acumulada de 6I,2 i una intensitat mitjana de 3,4. Fou especialment aguda al Ripollès $(6,3)$ i a l'Alt Urgell $(5,4)$.

I629-I630. Va ser la tercera crisi en intensitat de tot el període estudiat. Fou molt generalitzada ( $85,7 \%$ de les comarques estudiades) i amb una intensitat acumulada de $87,4 \mathrm{i}$ una intensitat mitjana de 4,9 . Fou especialment intensa al Vallès Occidental $(3,8)$, Garrotxa $(3,8)$, Alt Penedès $(4,8)$, Priorat (el I629, 2,4 i el I63I, 4,5), Anoia $(4,3)$, Berguedà $(4,9)$ i 
Alt Urgell $(5,9)$ i de manera destacada al Baix Penedès, on s'assoliren les intensitats més altes (6,I el I629 i 9,6 el I630). ${ }^{37}$

I64I-I644. Està directament relacionada amb les alteracions produïdes al voltant de la Guerra dels Segadors. Fou una de les grans crisis de la mortalitat adulta que afectà el 85,7 \% de les comarques estudiades i la intensitat acumulada arribava al 165,I, molt lluny de la crisi anterior que havia estat la tercera més intensa, amb 87,4 $\mathrm{i}$ amb una intensitat per comarca de 9,2. De fet, la crisi es va repartir entre aquells anys, de tal manera que en algunes comarques afectà un any i en d'altres, un altre. Fou pràcticament inexistent a la regió I. El I64I va ser molt dura a les comarques tarragonines: Tarragonès $(20,7)$, Baix Camp $(33,6)$, Conca de Barberà (Io,6), Alt Penedès $(6,5)$ i Priorat $(8,6)$. El I642 va continuar essent important a l'Alt Penedès $(5,8)$, la Conca de Barberà $(5,3)$ i el Segrià (7). El I643 afectà poques comarques i amb molt baixa intensitat, i es tornà a activar el I644, especialment a Osona $(4,2)$, Ripollès $(5,3)$ i l'Alt Urgell $(4, \mathrm{I})$. Les comarques tarragonines foren sens dubte les més afectades.

I647. És una crisi que afectà el 47,6 \% de les comarques estudiades i fou la de més baixa intensitat de totes les analitzades. Destaca la crisi de l'Alt Penedès $(4,4)$, el Priorat $(3,4)$ i el Baix Camp $(6,9)$, on va ser més forta. Continuaven localitzades a les comarques de Tarragona. És, de fet, una continuació de l'anterior.

I650-I655. Fou la crisi per excel.lència. Va afectar el 95,2 \% de comarques, i la que va tenir la intensitat acumulada $(202,3)$ i la mitjana (IO,I) més altes. Està directament relacionada amb la circulació de la pesta bubònica per Catalunya. ${ }^{38} \mathrm{Va}$ haver-hi zones molt castigades i d'altres

37. Un estudi específic d'aquesta crisi es pot trobar a Antoni Simón Tarrés, «Els anys I627-I632 i la crisi del segle XviI a Catalunya», Estudis d'Història Agrària, I992, pp. $157-180$.

38. Una bona geografia de la circulació de la pesta es pot trobar a Manuel CAMPS Clemente i Manuel Camps Surroca, La pesta de meitats del segle XviI a Catalunya, 
menys, a vegades en anys diferents. El I650 la Garrotxa $(13,7)$ va ser la zona més castigada i gairebé l'única. El I65I destaquen: Baix Penedès $(8,8)$, Conca de Barberà $(7,3)$ i Anoia $(4,5)$. El I652 les comarques més castigades foren: Baix Llobregat $(5,9)$, Maresme $(7,6)$ i Vallès Occidental (22) de la regió I; Garraf (9), Priorat (8), Anoia (7,8) i Segrià (5). El I653 afectà especialment Garraf (I2,7). El I654 poques comarques van patir crisis de mortalitat i el 1655 , la Garrotxa $(4,7)$, el Berguedà $(18,4)$ i el Solsonès $(6,6)$. Una estimació feta amb totes les dificultats estadístiques calcula que les defuncions se situaren entre 58.500 i 65.900 persones a tot Catalunya. ${ }^{39}$

I678-I679. Afectà el 66,7 \% de les comarques i fou una de les de menys intensitat mitjana $(2,8)$. Destaca la intensitat que va tenir al Vallès Occidental $(3,5)$, Garraf $(5)$ i el Berguedà $(4,5)$.

I684-I685. Afectà el 95,2 \%, gairebé totes les comarques estudiades, i fou la quarta en intensitat acumulada $(8 \mathrm{I}, 2)$ i en intensitat mitjana $(4, \mathrm{I})$. Va ser especialment intensa al Baix Llobregat $(6,9)$, el Maresme $(5,6)$, la Garrotxa $(7,8)$, el Ripollès $(5,7)$ i el Berguedà $(6,7)$.

I694-I695. Va ser la darrera de les crisis generals del segle XVII. Va afectar el 8I \% de les comarques estudiades i fou d'una intensitat mitjana modesta $(3,6)$. Fou especialment intensa al Maresme (4 el I694 i 6,3 el I695), el Baix Penedès $(5,5)$, el Berguedà $(4, \mathrm{I})$ i l'Alt Urgell $(5,5)$.

Enmig d'aquestes crisis generals hi havia molts anys de crisi que afectaven unes comarques i no unes altres. Destaquen, per exemple, una crisi d'intensitat de 9,7 al Garraf el I674, o una de 6,2 el I62I al Priorat. Hem d'insistir que estem observant sèries de 2I comarques i que d'algunes no en tenim cap gran representació, de tal manera que les dades exposades s'han de prendre amb precaució.

Seminari Pere Mata, 1985, pp. 47-48.

39. Narcís Castells, "La peste a mediados del siglo xvir en Catalunya», en I Congreso Hispano Luso Italiano de Demografía Histórica, 1987, pp. I04-II2. 
GrÀFIC 8. Comarques afectades per crisis de mortalitat adulta (I600-1700) (sobre 2I comarques)

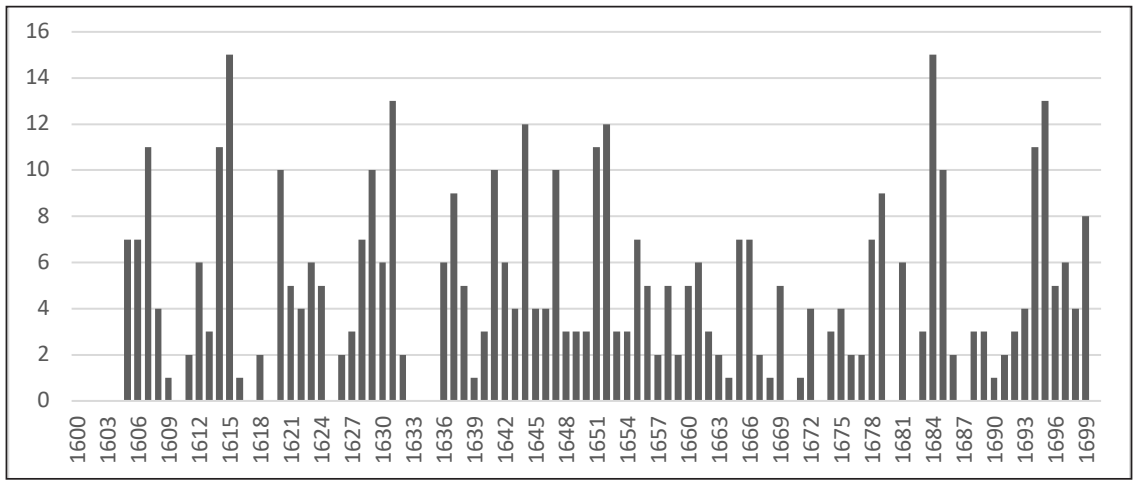

El gràfic 8 representa les comarques que presenten alguna crisi de mortalitat al llarg del segle. Es pot afirmar que sempre hi havia alguna comarca que manifestava un increment de la mortalitat per sobre de l'habitual i que, a vegades, aquesta crisi esdevenia generalitzada tal com hem mostrat més amunt. Només en tretze anys, del total estudiat no hi ha cap comarca que presenti cap crisi de mortalitat.

GrÀFIC 9. Intensitat mitjana de les crisis de mortalitat adulta a Catalunya (I600-1700)

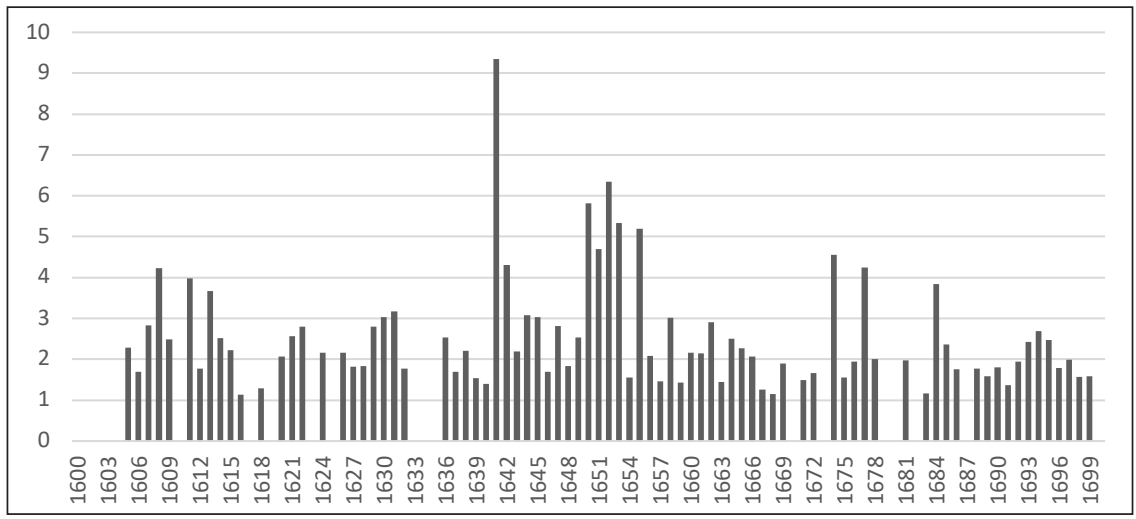


El gràfic 9 representa la intensitat mitjana de les diferents crisis de mortalitat que se succeïren al llarg del segle. És el resultat de dividir la intensitat acumulada cada any (sumant la intensitat de la crisi de cada comarca) pel nombre de comarques. Hom pot veure que les intensitats mitjanes tendeixen a estar la major part d'anys entre I i 2, i, per tant, eren crisis disseminades i poc intenses, però n'hi havia que incrementaven la intensitat d'una manera significativa que solia coincidir amb una extensió geogràfica de l'increment de la mortalitat. Destaquen totes les que hem esmentat més amunt, algunes de concentrades en un any com la de I64I sobretot, i d'altres escampades en un seguit d'anys com la de I650-I655.

La mortalitat catastròfica adulta, i hem de suposar que la d'albats, fou una de les causes que podria explicar el moderat creixement demogràfic del segle Xvir a Catalunya, una vegada es va aturar l'arribada d'immigrants francesos. Si agrupem les defuncions que considerem derivades de la mortalitat catastròfica, s'eleven al I4,4 \% del total de defuncions de la centúria (amb un màxim del 27,I \% per al període I640I660 i el I4,8 \% per als anys I68I-I700). Durant el segle XVIII, i realitzant el mateix càlcul, la mortalitat catastròfica de la centúria fou només del $6,7 \%$ i l'altre gran període de mortalitat entre el període I8oI-I820, la mortalitat catastròfica només va suposar el I5,I \%. Unes xifres molt lluny de les que es donaren al segle Xvir.

\section{La fecunditat a Catalunya al segle XVII}

Com es va comportar la fecunditat? Amb el mètode d'agregació de sèries parroquials no tenim gaires maneres d'acostar-nos a aquesta variable. Una de les poques fórmules és posar en relació els baptismes i els matrimonis, amb la idea que l'evolució dels baptismes té una relació directa amb els matrimonis si suposem una natalitat constant. Hi ha, però, altres elements que ho condicionen. Així, les crisis de mortalitat deixen molts vidus i vídues que poden tenir tendència a tornar-se a casar i a inflar els casaments, o a reduir la fecunditat davant la crisi, cosa que provoca una reducció de la fecunditat més elevada de la que es podria esperar. 
Tot i així, volem aportar algunes dades en aquest sentit. Hem reconstruït 89 sèries de baptismes i matrimonis que afecten el I5,I \% de la població estimada de I7I7. No hem utilitzat el mètode de relacionar baptismes i matrimonis per dècades com sol ser habitual, ${ }^{40}$ sinó que hem elaborat una sèrie amb el resultat anual d'aquest quocient $\mathrm{i}$ hem calculat una mitjana mòbil de 9 anys. Aquest sistema ens permet veure a llarg termini com va evolucionar la variable.

El gràfic io mostra l'evolució dels baptismes i matrimonis estudiats reduïts a base Ioo per poder-ne comparar l'evolució. Es pot afirmar que els matrimonis segueixen l'evolució dels baptismes amb dos matisos importants: per una banda, els matrimonis presenten més oscilllacions i, per l'altra, els matrimonis se separen dels baptismes durant el període de crisi de mortalitat que va de I630 a I660. Els dos matisos s'expliquen per la reacció de la gent a tornar-se a casar després de crisis de mortalitat que desfan els matrimonis. Totes les puntes dels matrimonis coincideixen bàsicament amb crisis de mortalitat. El matrimoni era un acte voluntari i s'adaptava a les conjuntures (disminuïa en moments de di-

GrÀFIC Io. Evolució dels baptismes i matrimonis a Catalunya $(\mathrm{I} 600-1700)$ a partir de 89 sèries $(\mathrm{I} 600-\mathrm{I} 609=\mathrm{IO0})$

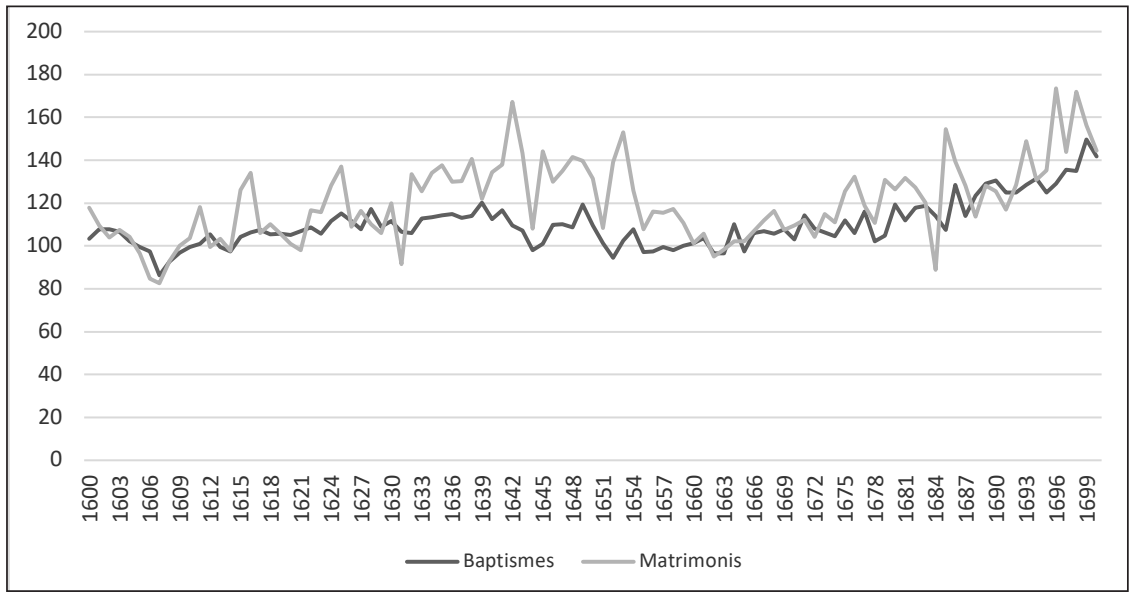

40. Louis Henry, Manual de demografía histórica, Crítica, Barcelona, I983. 
GrÀFIC II. Evolució de la relació baptismes/casaments a Catalunya (I600-1700) a partir de 89 sèries (mitjana mòbil de 9 anys)

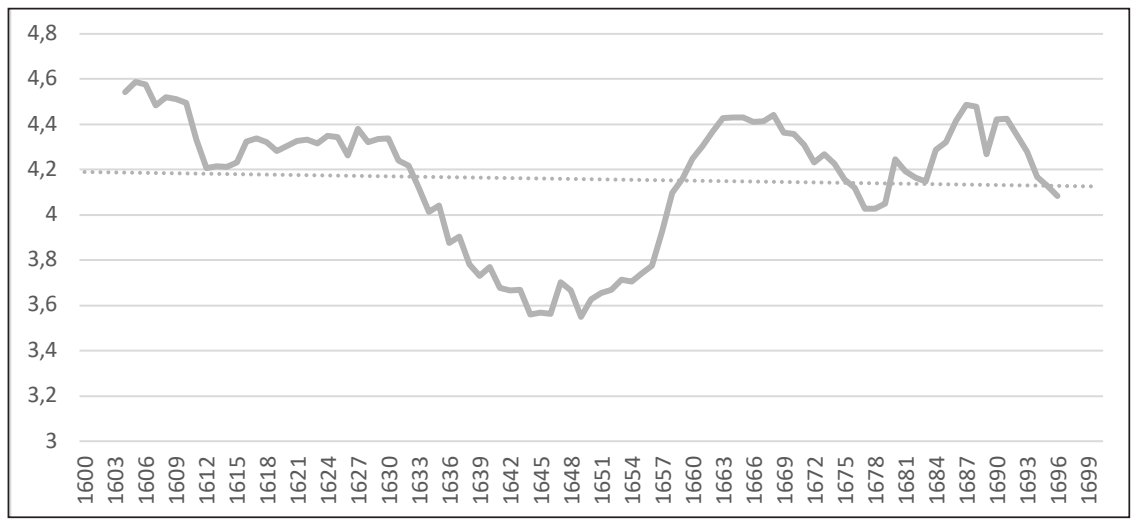

ficultat i s'hi acudia en temps de crisi refent les unions que havien quedat trencades o els casaments que s'havien endarrerit).

En el gràfic II es representa l'evolució de la relació entre baptismes i matrimonis. ${ }^{41}$ Segons la corba que dibuixa, la centúria va començar amb una fecunditat de 4,6 fills per matrimoni amb una tendència a la baixa fins a 4,2 per iniciar cap el I630 una davallada constant que arribà als 3,6. Aquesta reducció es deriva segurament de dos factors: en primer lloc, la caiguda de la fecunditat conseqüència de la Guerra de Segadors i el dur estrall de la pesta, que es reflecteix clarament en l'evolució dels naixements, i, en segon lloc, la recomposició de parelles després dels es-

4I. Aquestes dades es podrien corroborar amb les aportacions qualitatives de la reconstrucció de famílies. El nombre de fills està relacionat amb la intensitat del matrimoni, l'edat d'accés al matrimoni, els períodes intergenèsics, la mortalitat dels membres de la parella... i aquestes variables només es poden abordar des de la reconstrucció de famílies o amb un buidatge més qualitatiu dels registres parroquials. Els resultats, però, presenten moltes dificultats perquè es reconstrueixen petites poblacions i les famílies senceres que es poden refer sovint en són una part mínima. Probablement per això les dades que ens proporcionen són contradictòries i difícilment interpretables (vegeu la bibliografia de la nota 8). Un buidatge més qualitatiu Carmen XAM-MAR, «La població de la Seu d'Urgell als segles XVII i XVIII», tesi de llicenciatura, Universitat de Lleida, 1995. 
tralls demogràfics que inflen els matrimonis: això pot repercutir en aquesta caiguda. Tot i així són obvis i evidents els efectes que va tenir sobre la natalitat la dura crisi demogràfica de mitjan segle XVII.

A partir de 1657 es produeix una ràpida recuperació de l'indicador que assoleix, amb una lleugera tendència a la baixa, el nivell de començaments de segle. És alt o baix, aquest indicador? De fet, ho podem comparar amb algunes dades que tenim sobre el segle XviII elaborades amb el mateix mètode encara inèdites, en què aquesta relació se situa durant bona part del segle per sobre de $5.0^{42}$ En aquest sentit, la fecunditat del segle Xvir seria més baixa que la que es va donar al segle XVIII.

La conclusió que en podríem extreure és que el nombre de fills per matrimoni se situava al voltant de 4,5 , però que la crisi de mitjans de segle va reduir-la de manera significativa i el seu nivell fou inferior al del segle XVIII, quan es produí un important creixement demogràfic. Aquesta fecunditat moderada va ser també una explicació a l'estancament demogràfic de Catalunya al segle XVII.

\section{Conclusions}

La utilització d'un nombre important de sèries de baptismes de Catalunya per al segle XVII (I83), de defuncions (78) i de matrimonis (89) ens permet avançar en la definició i l'explicació de l'evolució demogràfica de Catalunya als segles XVI i Xviı. Les conclusions serien les següents:

42. Les dades de l'Alt Penedès i de Sant Pere de Riudebitlles corroboren l'increment del nombre de fills per matrimoni al segle XVIII respecte al segle XVII (MuÑoz, "Creixement demogràfic. Mortalitat i nupcialitat al Penedès (s. XVII-XIX)", pp. 253256; Àngels ToRrenTs, "Transformacions demogràfiques en un municipi industrial català: Sant Pere de Riudebitlles (I608-1935)», p. 364. També ho corroboren les dades recollides per Raimon Masdéu (4,OI segle XVII / 4,74 segle XVIII). Agraeixo a Raimon Masdéu que me les proporcionés. 
I. Hem redefinit el volum de població de Catalunya, que hem d'estimar més elevat que les xifres que s'han donat fins ara. El isıo es devia comptar amb una població de 317.000 persones, que podria haver arribat a 517.000 a finals del segle XVI i a 676.000 el I700, amb una forta davallada a mitjan segle XVII quan potser se situava als nivells del començament de la centúria (506.000). Nadal havia estimat 239.000 habitants el I5I5 i 508.000 el I7I7, i aquestes xifres ens permeten afirmar que estava entre un 40 i un $50 \%$ per sobre.

2. Hem pogut també definir unes etapes ben delimitades en aquest creixement: estancament entre I5IO i I540; un creixement accelerat a mitjan segle XVI (màxims I550-I559) que continuà fins a I630 una mica més suau, atribuït a l'aportació massiva de la immigració occitana; crisi duríssima provocada pels efectes de la Guerra dels Segadors i la pesta bubònica en què els baptismes i la població es devien situar al nivell de I600; finalment, un inici de recuperació, primer lent i que després s'accelerà fins a finals de segle, i que ja insinuava el que fou el creixement del segle XviII.

3. El segle XVII és, per tant, un segle d'estancament demogràfic. Els baptismes només creixen un $25 \%$ i tot el creixement es concentra a finals del període. L'estancament està relacionat amb la dura crisi de mitjan segle i l'evolució de la mortalitat.

4. Aquesta evolució demogràfica és desigual sobre el territori. La crisi és especialment dura a les comarques de Tarragona i a les terres de l'Ebre, en què a finals de segle amb prou feines s'arriba a la població de començaments del XVII. Altres zones (comarques de Girona, Catalunya central o comarques de Lleida) segueixen la mitjana de Catalunya. Hi ha també una Catalunya en què el creixement demogràfic es produeix al segle XVII i no al XVIII, que afecta les comarques d'Osona i Ripollès i que també s'insinua en les dades que tenim del Pirineu. Igualment, les comarques de Barcelona creixen per sobre de la mitjana, sobretot al Maresme.

5. Si s'analitza el creixement en funció de la grandària de la població, ens trobem amb la sorpresa que la crisi demogràfica és fonamentalment una crisi dels pobles i ciutats més grans, en què els baptismes arriben a caure un $29 \%$ i, a finals de segle, no havien recuperat el 
nivell inicial. Als altres pobles, la crisi és més suau i els resultats al final de la centúria són molt més elevats que la mitjana de Catalunya.

6. A l'hora d'intentar explicar aquest estancament ens hem fixat en la mortalitat. La relació defuncions/baptismes es manté molt alta (per sobre del $90 \%$ en moltes dècades) — per sobre del que és habitual- i hom detecta moltes dents de serra en la corba que ens indiquen la presència de nombroses crisis de mortalitat.

7. A part de mostrar la freqüència de crisis de mortalitat adulta en diferents comarques al llarg del segle XVII, hem descrit nou crisis de mortalitat que podem considerar generals i n'hem calculat la intensitat en cada cas. Les més generalitzades foren les de 1650-1655 i I684-I687, i les més intenses la de I64I-I644 i la de I650-I655. La mortalitat catastròfica (I4,4 \% durant tot el segle, front al 6,7 \% durant el segle XVIII) ajuda a explicar la moderació del creixement de la població.

8. S'han aportat dades sobre la relació entre baptismes/matrimonis per acostar-nos a l'evolució de la fecunditat de manera molt imprecisa. S'arrenca amb 4,6 fills per matrimoni i s'acaba amb 4,4. Destaca, però, l'espectacular caiguda fins a 3,6 fills per matrimoni durant la profunda crisi de mitjan segle XvII, que al seu torn s'explica per la crisi mateixa i per la recomposició de matrimonis, que s'incrementen de manera significativa. Aquest indicador, que explica també l'estancament demogràfic, està per sota dels resultats que s'obtenen per al segle XVIII (per sobre de 5 la primera meitat de segle).

9. Com a conclusió final: l'estancament de la població durant el segle XVII s'explica per la interrupció de l'arribada d'occitans cap el I630, per una mortalitat molt alta relacionada amb crisis de mortalitat —alguna de les quals extraordinària, per exemple la de I650-I655i el trasbals de la Guerra dels Segadors, i una fecunditat moderada agreujada també per la crisi mateixa. El I680 ja es notaven símptomes de recuperació, que continuà amb molta intensitat al segle XVIII. Un creixement i un estancament que es van repartir de manera diferent sobre el territori. 


\section{Apèndix I. Sèries analitzades del segle XVII i procedència}

Claus per saber les sèries utilitzades en cada cas.

I. Sèrie de baptismes (I510-I700)

2. Sèrie de baptismes (I550-I700)

3. Sèrie de baptismes (I565-1700)

La resta, I600-I700.

(b)sèries de baptismes a la comarca

(d) sèrie de defuncions que hem pogut reconstruir

(c) sèrie de matrimonis

\section{REGIÓ I}

Baix Llobregat (I2b / $7 \mathrm{~d} / \mathbf{4 c})^{43}$

Abrera (3) (d), Begues (3), Castellví, Corbera, el Papiol (3) (d) (c), Martorell, Olesa de Montserrat (d), Sant Andreu de la Barca (3) (d) (c), Sant Climent de Llobregat (3) (d) (c), Sant Feliu de Llobregat (d), Santa Coloma de Cervelló (3), Torrelles (3) (d) (c).

43. Carles Millàs Castellví, Estudi demogràfic de la parròquia de Santa Eulalia del Papiol (I565-I799) (Ajuntament del Papiol, el Papiol, 1993); Carles Millàs Castellví, La natalitat en el Baix Llobregat en un periode de crisi. El segle XVII (Universitat de Barcelona, Barcelona, I996); F. Xabier Gual Ramírez i Carles Millàs Castellví, «La mortalitat al Baix Llobregat en un període de crisi: Segle XviI", Materials del Baix Llobregat, 3 (I997), pp. 2II-2I3; Carles Millàs Castellví, "Aproximació a l'estudi de les migracions històriques a escala municipal: Olesa de Montserrat, I58I-I930", tesi doctoral, Universitat Autònoma de Barcelona, 20I5; Carles Perpinyà, «Aspectes sanitaris dels arxius parroquials de la regió central del Baix Llobregat (S. XVI-XVIII)», tesi doctoral, Universitat de Barcelona, I988; F. Xabier Gual Ramírez, "La mortalitat al Baix Llobregat en un període de crisi, el segle XviI», tesi de llicenciatura, Universitat de Barcelona, 1996. He d'agrair al Centre d'Estudis Demogràfics que em posessin a disposició la sèrie de Sant Climent de Llobregat. També ha estat molt útil el CD amb dades demogràfiques de la tesi de Carles Millàs, ja esmentada. 
Barcelonès ( $2 \mathrm{~b} / \mathrm{Id} / \mathbf{2 c})^{44}$

Sant Just Desvern (2) (c), ${ }^{45}$ parròquia de Sant Just i Pastor de Barcelona (I) (d) (c).

Maresme (I5b / Iod / I3c) $)^{46}$

Alella (3) (d), Arenys de Mar (3) (d), Arenys de Munt (2) (d), Cabrera (2) (d), Canet (d), Dosrius (2) (d), Malgrat de Mar (3) (d), Mataró (I),

44. Juan Alberto Spuch Sánchez, "Aspectos sanitarios de los Archivos parroquiales de la Iglesia de San Justo y San Pastor de Barcelona, siglo XvII», tesi doctoral, Universitat de Barcelona, I99I; Raimon MASDÉU, «Reconstrucció de famílies de la parròquia de Sant Just Desvern (I509-1936). Un estudi de demografia històrica», tesi doctoral, Universitat Autònoma de Barcelona, 20I6; Jordi Andreu Sugranyes i Antoni SimÓn TARRÉs, «Evolució demogràfica (segles XVI i XVII)», a Història de Barcelona. Barcelona dins la Catalunya Moderna (segles XVI-XVII), Fundació Enciclopèdia Catalana, Barcelona, I992.

45. Actualment Sant Just Desvern forma part de la comarca del Baix Llobregat.

46. Alexandra Capdevila, Entre la vinya i el comerç: els origens de l'expansió econòmica del Maresme a l'època moderna, Documenta Universitaria, Girona, 2oro; Conrad Curtó, «Aspectes sanitaris de Sant Feliu de Cabrera, Sant Genís de Vilassar, Sant Joan de Vilassar i Creu de Cabrils (segles XVI, XVII i XVIII)», tesi doctoral, Universitat de Barcelona, I990; Carles Díaz MarTí, La població d’Alella als segles XVI, XVII $i$ XVIII, Ajuntament d'Alella, Alella, 2006; «Estadística parroquial de 1509 a 1955 y contribución al estudio de la demografía comarcal», Parroquia de Sant Andrés de Llavaneras, 38 (I956); Jose Ramis Nieto, «Els arxius parroquials de Dosrius: font per a l'estudi de la demografia local», 2016, https://adosrius.wordpress.com/2016/o7/Io/els-arxius-parroquials-de-dosrius-font-per-a-lestudi-de-la-demografia-local/; Josep Ramis Pujol, «Aspectes sanitaris de l'arxiu de Santa Maria de Mataró durant els segles XVI, XVII i primera meitat del XVIII", tesi doctoral, Universitat de Barcelona, I994; Joaquim RECaÑo, Àngels Torrents i Miquel Valls, Informatització de les sèries de baptismes, matrimonis i enterraments de Catalunya (sèries subministrades per Jordi Nadal), Universitat Autònoma de Bellaterra, Centre d'Estudis Demogràfics, s.d.; Carme Ros, Les estratègies familiars $i$ la mobilitat social dels menestrals a Catalunya: segles XVII-XIX. El cas de Mataró, Barcelona, 2003; Enric SubIÑà Coll, «La població moderna a Dosrius. Estudi demogràfic (segles XVI-XVIII)", Duos Rios, 2 (2008), pp. 24-37; Neldo Trujillo Bencomo, «Aspectos sanitarios de los archivos parroquiales de Arenys de Mar y Arenys de Munt", tesi doctoral, Universitat de Barcelona, I990. Agraeixo a Alexandra Capdevila i Enric Subinyà que posessin a la meva disposició diverses sèries del Maresme. 
Premià de Dalt, Sant Andreu de Llavaneres (3), Sant Cebrià de Vallalta (I), Sant Genís de Vilassar (I) (d), Sant Pol de Mar (I) (d), Tiana-Montgat, Tordera (2) (d).

Vallès Oriental ( $\mathbf{4} 4 \mathrm{~b} / 4 \mathrm{~d} / \mathbf{9 c})^{47}$

L'Ametlla del Vallès (3) (d) (c), Bigues (3) (c), Cànoves (3) (c), Lliçà de Munt (3) (d) (c), Malanyanes (3) (c), Martorelles (2), Montmeló (3), Olzinelles, Palaudàries(c), Sant Celoni (3) (d), Sant Feliu de Codines (3) (d) (c), Vallgorguina (c), Vilanova de la Roca (c), Vilardell.

Vallès Occidental $(5 \mathrm{~b} / 3 \mathrm{~d} / 3 \mathrm{c})^{48}$

Castellbisbal, Sant Cugat del Vallès (2) (d) (c), Sant Pere de Terrassa, Sant Quirze de Terrassa (d) (c) i Sentmenat (2) (d) (c).

\section{REGIÓ $_{2}$}

Alt Empordà $(9 \mathrm{~b} / 3 \mathrm{c})^{49}$

Agullana, Cabanes, Castelló d'Empúries (I) (c), Espolla (2), Llançà (c), Lledó d'Empordà, Navata, Ordis (c), Ventalló.

47. Miquel Heimann, «Aspectes sanitaris de la Vall de Tenes (Baronia de Montbui) en els segles XVII i XvıII», tesi doctoral, Universitat de Barcelona, I995; Josep R. Toll Clavero, «Aspectes sanitaris de Sant Celoni (I567-I800)», tesi doctoral, Universitat de Barcelona, I992; Jaume DANTí Riu, «El Vallès Oriental a l'època moderna: el creixement demogràfic i econòmic als segles XVI i XVII», Universitat de Barcelona, 1986. Agraeixo a Ramon Rodés que em facilités dades de Sant Feliu de Codines.

48. Daniel Montañá Buchaca, Aspectes sanitaris dels arxius de les parròquies del terme $i$ vila de Terrassa als segles XVI, XVII $i$ XVIII, Seminari Pere Mata, Barcelona, 1987. He d'agrair a Enric Tello que em facilités la sèrie de Sentmenat, a Joaquim Torras Sallés la de Sant Cugat del Vallès i Valldoreix i a Xavier Riera Hernández les dades de Castellbisbal a partir d'un treball de grau tutoritzat per Valentí Gual. Vegeu també F. Xavier Riera Hernández, Castellbisbal, dos segles i mig d'estudi demogràfic, Ajuntament de Castellbisbal, Castellbisbal, 202I.

49. Miquel Planas Roig, «La població de l'Alt Empordà al règim demogràfic antic», tesi de llicenciatura, Universitat Autònoma de Barcelona, 1985. La sèrie de Llançà forma part de les sèries de Jordi Nadal conservades al Departament d'Història i Institucions Econòmiques de la Universitat de Barcelona. 
Baix Empordà ( $5 \mathrm{~b} / \mathrm{Ic})^{50}$

Begur, la Bisbal d'Empordà (I) (c), Palamós (3), Sant Feliu de Guíxols, Torroella de Montgrí (3).

Garrotxa (2b / Id / Ic $)^{\text {II }}$

Olot (d) (c), les Preses.

Gironès $(\mathbf{2} b)^{52}$

Cassà de la Selva, Girona (tres parròquies) (I).

La Selva $(5 \mathbf{b})^{53}$

Blanes (2), Caldes de Malavella (2), Santa Coloma de Farners, Tossa de Mar (3), Vilobí d’Onyar.

50. Jaume PorTella, "Estudi demogràfic del prelitoral gironí (s. XVI-XVIII)», a Treballs d'història. Estudis de demografia, economia $i$ societat a les comarques gironines, Girona, I976, pp. 35-6i; Recaño, Torrents, Valls, Informatització de les sèries de baptismes, matrimonis i enterraments de Catalunya; Yvette BARBAZA, "Paysage rural et structure agraire du littoral nord catalan au xvinème siècle», Bulletin de l'Association de Géographes Français, I96I, pp. 86-I09. La sèrie de Sant Feliu de Guíxols procedeix del Departament d'Història i Institucions Econòmiques. La sèrie de Palamós m'ha estat cedida per Pere Trijueque

5I. Manuel Cahissa Mur, "Aspectes sanitaris de la parròquia d'Olot (I60oI699)», tesi doctoral, Universitat de Barcelona, I994. La sèrie de les Preses procedeix del buidatge que es troba al Web de la Societat Catalana de Genealogia.

52. Ramon Alberch i Antoni Simón Tarrés, "L'evolució demogràfica de Girona en els segles XVI i XVII a través dels registres parroquials», Estudi General, I982, pp. II-3I; Nadal i Giralt, La population catalane de I553 à I7I7.

53. Portella, «Estudi demogràfic del prelitoral gironí (s. XVI-XVIII)»; BarbazA, «Paysage rural et structure agraire du littoral nord catalan au XviIIème siècle»; Josep Maria Millàs i Francesc Rabassa, Historia de Santa Coloma de Farners y su comarca, Junta del Milenio de Santa Coloma, Santa Coloma de Farners, I95I. La sèrie de Vilobí d'Onyar procedeix del buidatge de Marta Lleopart, que es troba a la Societat Catalana de Genealogia. 
Pla de l'Estany $(3 \mathbf{b})^{54}$

Banyoles, Crespià (3), Sords.

\title{
REGIÓ $_{3}$
}

Alt Camp (5b) (Ic)ss

Alcover (3), Bràfim (2), Puigtinyós (3), Valls (2) (c), Vila-rodona.

\author{
Alt Penedès $(9 \mathrm{~b} / 7 \mathrm{~d} / 3 \mathrm{c})^{56}$ \\ Gelida, Mediona (d) (c), Pacs (d), Sant Llorenç d'Hortons (d), Sant Pere \\ de Riudebitlles (d) (c), Santa Margarida i els Monjos (d), Sant Sadurní \\ d'Anoia (3) (c), Vilafranca del Penedès (d), Vilobí del Penedès (d).
}

\author{
Baix Penedès (4b / Id/ Ic) $)^{57}$ \\ Banyeres, Bisbal de Penedès, Montmell (3), Vendrell (3) (d).
}

54. Dolors Terradas, "La població de la Vall del Terri (s. Xv-Xx)», a Cornellà de Terri. Pregons i estudis, Ajuntament de Cornellà de Terri, Cornellà de Terri, I986, pp. 67-98; J. Tremoleda i Trilla, coord., Història del Pla de l'Estany, Diputació de Girona, Girona, 2000.

55. Francesc Olivé, «Valls de la crisi del segle Xvi a la recuperació econòmica del segle XvirI. La ciutat, les viles, la comarca: un estudi de la terra i de la seva gent al llarg de l'Antic Règim», tesi de doctorat, Universitat de Barcelona, I989; Josep Comas, «Demografia i societat rural a Vila-rodona durant l'Antic Règim (s. XVI-XVIII)», tesi de llicenciatura, Universitat de Barcelona, I986; Jordi Andreu Sugranyes, «El Camp de Tarragona i el Priorat durant els segles XVIII i XIX: les bases demogràfiques, agràries i comercials de l'expansió setcentista», tesi de doctorat, Universitat Autònoma de Barcelona, 1994. Agraeixo a Francesc Olivé que em proporcionés les dades per poder reconvertir els números índex.

56. Francisco Muñoz Pradas, «Creixement demogràfic, mortalitat i nupcialitat al Penedès (segles XVII-XIX)», tesi de doctorat, Universitat Autònoma de Barcelona, I99I; Àngels Torrents, Transformacions demogràfiques en un municipi industrial català: Sant Pere de Riudebitlles.

57. Muñoz Pradas, "Creixement demogràfic, mortalitat i nupcialitat al Penedès (segles XVII-XIX)»; Antonio VICENTE, «Aspectos sanitarios de los archivos parroquiales del Vendrell (I580-I800)», tesi de doctorat, Universitat de Barcelona, I987; Salvador Caralt Calvo, "Evolució demogràfica del Vendrell (s. XVI-XIX)», tesi de llicenciatura, Universitat Autònoma de Barcelona, 1986. Treball de curs d'Eva Marcé Batet (20I2). 
Garraf $(3 \mathbf{b} / \mathbf{2 d} / \mathbf{I c})^{58}$

Vilanova (d) (c), la Geltrú (d), Sitges.

Tarragonès $(3 \mathrm{~b} / \mathbf{2 d} / \mathbf{2 c})^{59}$

Creixell (d) (c), el Catllar, Tarragona (3) (d) (c).

\section{REGIÓ $_{4}$}

Baix Camp $(8 \mathrm{~b} / 4 \mathrm{~d} / 5 \mathrm{c})^{60}$

Aleixar (3) (d) (c), Almoster (3), Borges del Camp, Botarell (d) (c), Pratdip, Reus (3) (d) (c), Riudecanyes (3) (d) (c), Riudoms (3) (c).

Conca de Barberà (23b / I8d / I5c $)^{6 \mathrm{I}}$

Aguiló (2) (d), Barberà de la Conca (d), Belltall (d) (c), Blancafort, Conesa (3) (d) (c), Figuerola (d) (c), Forés (3) (d) (c), Guàrdia dels Prats, Montargull (c), Montbrió de la Marca (d), Passanant (d) (c), Pira (d) (c), Pontils (d) (c), Rocafort (3) (d), Rojals, Santa Coloma Queralt (2) (d) (c), Santa Perpètua de Gaià (d) (c), Vallclara (3) (d) (c), Vallespi-

58. Muñoz Pradas, «Creixement demogràfic, mortalitat i nupcialitat al Penedès (segles XVII-XIX)»; Pere Serramalera Cosp, «Estudi demogràfic de la vila de Sitges des del segle xIv fins al Xviı̀̀̀, Miscellània Penedesenca, I990, pp. 252-263.

59. Roser LozAno, «Tarragona al segle xviI: aspectes demogràfics d'una població d'Antic Règim", tesi de llicenciatura, Universitat de Barcelona, I982; Josep Lluís Grasa Muro, «Aspectos demográficos del archivo diocesal de la catedral de Tarragona, I550-I700", tesi de doctorat, Universitat de Barcelona, I988; NADAl I Giralt, La population catalane de 1553 à 1717 . L'immigration française et les autres facteurs de son développement; Andreu Sugranyes, El Camp de Tarragona i el Priorat durant els segles XVIII $i$ XIX.

6o. Jordi Andreu, Població i vida quotidiana a Reus durant la crisi de l'Antic Règim (I700-1850), Centre de Lectura de Reus, Reus, 1986; Jordi Andreu Sugranyes, El Camp de Tarragona i el Priorat durant els segles XVIII $i$ XIX; Morell TorradamÉ, Demografia de Reus i la seva àrea d'influència a l'època moderna; Francesc X. Lladó, "Aspectes sanitaris de l'arxiu parroquial de Sant Pere de Reus, I588-I700", tesi de doctorat, Universitat de Barcelona, Barcelona, 1995.

6I. Valentí GuAL, «Balanç natural i reconstrucció de famílies a través dels sacramentaris. La Conca de Barberà a l'època moderna», tesi de doctorat, Universitat de Barcelona, I99I. 
nosa (d) (c), Vilanova de Prades (d) (c), Vilaverd (3) (d) (c), Vimbodí (d), les Piles (d) (c).

Priorat $(6 \mathrm{~b} / 4 \mathrm{~d} / 3 \mathrm{c})^{62}$

Cabassers (2), Cornudella (I) (d) (c), Falset, Poboleda (2) (d) (c), Torroja (I) (d), Ulldemolins (I) (d) (c).

REGIÓ s

Baix Ebre (2b / Id $)^{63}$

Tortosa (I), Paüls.

Terra Alta (Ib / Id / Ic) ${ }^{64}$

Gandesa (3) (d) (c).

\section{REGIÓ 6}

Osona $(9 \mathrm{~b} / 4 \mathrm{~d} / 8 \mathrm{c})^{65}$

62. Andreu Sugranyes, El Camp de Tarragona i el Priorat durant els segles XVIII $i$ XIX; Jordi Pau RoIGÉ, Aspectes sanitaris dels arxius parroquials del Priorat (segles XVIXVIII), Seminari Pere Mata, Barcelona, I992.

63. Emeteri Fabregat Galcerà, «L'evolució demogràfica del Baix Ebre i Montsià (I7OI-I900)", treball d'investigació, Universitat Autònoma de Barcelona, 2002; Emeteri FABREgat GalCERÀ, "Bateigs i enterraments: creixement demogràfic al Baix Ebre i Montsià als segles XVIII i XIX", Recerca. Centre d'Estudis Comarcals del Baix Ebre, 8 (2004), pp. I5-68; Antoni Bordas Belmonte, La comunitat cristiana de Paüls. L'autor, Paüls, I989.

64. Joan Baptista Manyà, Notes històriques de Gandesa, Algueró i Baigés, Tortosa, 1962.

65. Miquel Vilardell, «Aspectes sanitaris d'Osona: el Lluçanès en els segles XVI, XVII i XVIII", tesi de doctorat, Universitat de Barcelona, I992; Manuel AldeA, "Aspectes sanitaris de Santa Coloma de Centelles i Sant Fruitós de Balenyà (s. XVII i XVIII)», tesi de doctorat, Universitat de Barcelona, I993; Joaquim Recaño, Àngels Torrents, i Miquel Valls, Informatització de les sèries de baptismes, matrimonis i enterraments de Catalunya; Josefina Badia, Joana SAla, i Elisabeth València, «De la demografia de tipus antic (XVII) cap al cicle de demografia moderna», treball inèdit, I983; Rafel GINEBRA, «Naixements i noms al Collsacabra els segles XVI i XVII. L'exemple de Tavertet», Els Cingles de Collsacabra, 2007. 
Alpens (3) (c), Centelles (2) (d) (c), Lluçà (3) (d) (c), Olost (c), Prats de Lluçanès (3) (d) (c), Sant Boi de Lluçanès (c), Sant Feliu de Torelló (d) (c), Sant Pere de Torelló, Sora (c), Tavertet (2).

Ripollès $(6 \mathrm{~b} / \mathrm{Id} /)^{66}$

Camprodon, Molló, Sant Joan de les Abadesses (3) (d), Vallfogona de Ripollès (2), Sant Llorenç de Campdevànol (3), Ogassa, Ripoll (2). ${ }^{67}$

\section{REGIÓ 7}

Anoia $(\mathrm{Iob} / 3 \mathrm{~d} / 7 \mathrm{c})^{68}$

Bellprat, Bruc (3), Clariana (3) (c), Copons (3) (d) (c), Igualada (2) (d) (c), Òdena (3) (c), Pobla de Claramunt (2), Pujalt (3) (d) (c), Segur (2) (c), Veciana (c).

Bages $(4 b / 3 c)^{69}$

Aguilar (3), Avinyó (c), Sant Salvador de Guardiola (c), Santa Maria d'Oló (2) (c).

66. Joaquim Torras Sallés, «Aspectos sanitarios de los archivos parroquiales del arciprestazgo de Sant Joan de les Abadesses durante los siglos XVI, XVII y XVIII", tesi de doctorat, Universitat de Barcelona, I993; Josep Grau Galtés, «Aspectes sanitaris dels arxius parroquials de l'antiga vegueria de Ripoll Campdevànol (s. XVI, XviI i XVIII)», tesi de doctorat, Universitat de Barcelona, I994; Rosa Ribas Garcia, «Estructura demogràfica de la vila de Ripoll en el segle XviI", Annals del Centre d'Estudis Comarcals del Ripollès, 1983, pp. 6780.

67. Només tenim dades de Ripoll per aquest període, però no tenim la sèrie completa pel que fa al segle XVII.

68. Xavier Jorba Serra, "La demografia d'Òdena i Rubio a l'edat moderna», Miscel.lània Aqualatensia, I2 (2006), pp. 65-I42; Xavier Jorba SERRA, «Una comunitat rural de la Catalunya Interior. Òdena (segles XVI-XVII)», tesi de doctorat, Universitat de Barcelona, 20IO; Josep M. Torras RibÉ, «Demografia i societat a Igualada durant els segles XVI i XVII", Miscellània Aqualatensia, 1987, pp. 87-I09. Agraeixo a Magda Vives la cessió de la sèrie d'Igualada.

69. Llorenç Ferrer-Alòs, «Aproximació a l'estructura agrària de la comarca del Bages en el segle XVIII i primera meitat del segle XIX », tesi de doctorat, Universitat de Barcelona, 1985 . 
Solsonès $(\mathrm{Ib} / \mathrm{Id} / \mathrm{Ic})^{70}$

Solsona (3) (d) (c).

Berguedà $(3 \mathrm{~b} / \mathrm{Id} / \mathrm{Ic})^{7 \mathrm{I}}$

Berga (3) (d) (c), Puig-reig, Casserres.

\section{REGIÓ 8}

Segrià $(3 \mathrm{~b} / 2 \mathrm{~d})^{72}$

Almatret (d), Lleida (d), Seròs.

Urgell $(4)^{73}$

Anglesola (2), Verdú (2), Vilagrassa (2), Tàrrega (2).

\section{Segarra $(\mathbf{I})^{74}$}

Torà (2).

70. Ramon Planes Albets, «El creixement econòmic del segle xvin a la Catalunya Interior: aproximació al cas del Solsonès i la seva comarca», tesi de llicenciatura, Universitat de Barcelona, 1983; Lluís Sallés Planes, «Aspectes sanitaris de l'Arxiu Parroquial de Solsona (I565-1700)», tesi de doctorat, Universitat de Barcelona, I994.

7I. Lluís Guerrero Sala, "Aspectes sanitaris de la vila de Berga (I560-I760)», tesi de doctorat, Universitat de Barcelona, 2006. Agraeixo a Josep Albert Planas la cessió de la sèrie de Casserres. La de Puig-reig és d'elaboració pròpia.

72. Manuel Camps Clemente i Manuel Camps Surroca, Aspectes sanitaris de l'arxiu de Sant Joan de Lleida, Seminari Pere Mata, Barcelona, 1983; Josep Pujol BalLESTÉ, «Poblament i despoblament al Segrià del segle XVII», tesi de doctorat, Universitat de Barcelona, 2012.

73. Planes Closa, Demografia i societat de Tàrrega i de l'Urgell; Josep M. Planes ClosA, «Natalitat i evolució demogràfica a L'Urgell dels segles XvI/XvII», Urtx: revista cultural de l'Urgell, i2 (1999), pp. 6374. María José Vilalta Escobar, "Població, família i treball a la Lleida del segle xvI», tesi de doctorat, Universitat de Barcelona, I991.

74. Elaboració pròpia. 
REGIÓ $9^{75}$

Alt Urgell (3b / Id /Ic)

La Vansa, Sant Miquel de la Seu d'Urgell, Sant Ot de la Seu d'Urgell

(d) (c).

75. Xam-Mar, «La població de la Seu d'Urgell»; Antoni Vila Fumàs, «Aspectes sanitaris de la parròquia de Sant Ot de la Seu d'Urgell (segles XviI i XVIII)", tesi de doctorat, Universitat de Barcelona, I995. La sèrie de la Vansa és d'elaboració pròpia.

Pedralbes, 4I (2O2I), 9I-I42, ISSN: O2II-9587, DOI: IO.344/PEDRALBES2O2I.4I.3 


\section{Annex 2. Evolució anual dels baptismes a Catalunya (I600-I700) per regions}

\begin{tabular}{|c|c|c|c|c|c|c|c|c|c|c|}
\hline \multirow[b]{2}{*}{ Sèries } & \multicolumn{10}{|c|}{ Evolució anual dels baptismes a Catalunya (I600-I700) per regions } \\
\hline & 48 & 26 & 24 & 37 & 3 & 16 & I8 & 8 & 3 & 183 \\
\hline & regió I & regió 2 & regió 3 & regió 4 & regió 5 & regió 6 & regió 7 & regió 8 & regió 9 & Catalunya \\
\hline 1600 & $94 \mathrm{I}$ & I. 222 & I.I26 & 780 & 305 & 306 & 472 & 279 & 54 & 5.486 \\
\hline I6OI & I.I27 & I. 244 & 1.136 & 835 & 305 & 362 & 457 & $3 \mathrm{I} 7$ & 35 & 5.819 \\
\hline 1602 & 1.062 & I. 224 & I.200 & 729 & 308 & 294 & 467 & 301 & 44 & 5.630 \\
\hline 1603 & I.OI8 & I. 245 & I.O28 & 749 & 277 & 335 & 449 & 325 & 83 & 5.508 \\
\hline I604 & 984 & I.I4O & 1.076 & 726 & 286 & $3 \mathrm{IO}$ & 477 & 297 & 75 & 5.370 \\
\hline 1605 & 972 & I.I8I & I.O48 & 686 & 290 & $28 \mathrm{I}$ & 409 & 335 & 65 & 5.267 \\
\hline 1606 & 919 & I.084 & I.O43 & 714 & $29 \mathrm{I}$ & 256 & 455 & 360 & 34 & 5.156 \\
\hline 1607 & 828 & I.O22 & $95 \mathrm{I}$ & 657 & 287 & 255 & 386 & 336 & 45 & 4.767 \\
\hline 1608 & 878 & I. 053 & 1.069 & 683 & 252 & $26 \mathrm{I}$ & 403 & 359 & 42 & 5.001 \\
\hline 1609 & 916 & I.II9 & I.029 & 707 & 245 & 273 & 394 & 348 & 84 & $5 . \mathrm{II} 4$ \\
\hline I6IO & 939 & I.I7I & I.OI5 & 725 & 254 & 342 & 429 & 320 & 98 & 5.294 \\
\hline I6II & I.O7I & I.I59 & I.086 & 747 & 242 & 338 & 391 & 359 & 78 & 5.472 \\
\hline I6I2 & I.032 & I.I48 & I.I2O & 718 & 264 & 350 & 424 & 346 & 85 & 5.487 \\
\hline I6I3 & 993 & I.165 & I.O42 & 742 & 260 & 350 & 444 & 368 & 73 & 5.437 \\
\hline I6I4 & 1.003 & I.045 & I. 058 & 746 & 216 & 309 & $38 \mathrm{I}$ & 328 & 83 & 5.169 \\
\hline 1615 & 1.069 & I. 238 & I.O25 & 694 & 246 & 320 & 447 & 315 & $7 \mathrm{I}$ & 5.425 \\
\hline 1616 & I.082 & I.229 & I.I33 & $74 \mathrm{I}$ & 263 & 364 & 479 & 379 & 96 & 5.766 \\
\hline 1617 & 1.053 & $\mathrm{I} .267$ & 1.059 & $83 \mathrm{I}$ & 248 & 382 & 454 & 388 & 74 & 5.755 \\
\hline 1618 & 1.055 & I.208 & I.III & 689 & 232 & 353 & 479 & $35 \mathrm{I}$ & 75 & $5.55 \mathrm{I}$ \\
\hline I6I9 & 995 & I.I79 & 1.089 & 780 & 316 & 363 & 469 & 367 & 69 & 5.626 \\
\hline I620 & I.008 & I.I44 & I.094 & 793 & 242 & $4 \mathrm{IO}$ & 477 & $4 \mathrm{I} 6$ & 69 & 5.653 \\
\hline 1621 & 999 & I.I84 & I.I2I & 738 & 280 & 346 & 450 & 388 & $5 \mathrm{I}$ & 5.556 \\
\hline I622 & 1.052 & I. 262 & I.I47 & 799 & 270 & 362 & 499 & 394 & 6I & 5.845 \\
\hline 1623 & I.06I & I.I97 & I.I 54 & $8 \mathrm{I} 4$ & 265 & 382 & 422 & 427 & 52 & 5.772 \\
\hline 1624 & 1.095 & I. 240 & I.I22 & 776 & 267 & 339 & 472 & 392 & 55 & 5.758 \\
\hline 1625 & I.I55 & I. 374 & I.IO9 & 784 & 295 & 385 & 457 & $4 \mathrm{IO}$ & 62 & $6.03 \mathrm{I}$ \\
\hline 1626 & I.I54 & $\mathrm{I} .270$ & I.I59 & 798 & 253 & 356 & $46 I$ & 400 & 37 & 5.888 \\
\hline 1627 & I.057 & I. 243 & I.I28 & 625 & 273 & 385 & 446 & 382 & 67 & 5.606 \\
\hline
\end{tabular}

(Continua a la pàgina següent)

Pedralbes, 4I (202I), 9I-I42, ISSN: O2II-9587, DOI: IO.344/PEDRALBES2O2I.4I.3 


\begin{tabular}{|c|c|c|c|c|c|c|c|c|c|c|}
\hline \multirow[b]{2}{*}{ Sèries } & \multicolumn{10}{|c|}{ Evolució anual dels baptismes a Catalunya (I600-I700) per regions } \\
\hline & 48 & 26 & 24 & 37 & 3 & 16 & I8 & 8 & 3 & 183 \\
\hline & regió I & regió 2 & regió 3 & regió 4 & regió 5 & regió 6 & regió 7 & regió 8 & regió 9 & Catalunya \\
\hline 1628 & I. 232 & I. $4 \mathrm{I} 8$ & I.049 & 747 & 267 & 380 & 457 & $4 \mathrm{I} 7$ & 69 & 6.035 \\
\hline 1629 & I.066 & $\mathrm{I} .328$ & I.046 & 679 & 280 & 380 & 435 & 382 & $7 \mathrm{I}$ & 5.667 \\
\hline 1630 & I.2OI & I.I64 & 980 & 732 & 284 & 406 & 416 & $4 \mathrm{OI}$ & 87 & 5.669 \\
\hline 1631 & I.064 & 1.160 & I.O47 & 685 & 327 & 346 & $4 \mathrm{I} 8$ & 366 & 70 & 5.482 \\
\hline 1632 & I.106 & I.219 & I.052 & 674 & 270 & $38 \mathrm{I}$ & 463 & 380 & 64 & 5.608 \\
\hline 1633 & $\mathrm{I} .2 \mathrm{I} 3$ & I. 247 & 1.089 & $7 \mathrm{I} 4$ & 254 & $4 \mathrm{I} 2$ & 437 & 403 & $8 \mathrm{I}$ & 5.849 \\
\hline 1634 & I. 202 & I. 200 & I.084 & 673 & 277 & 398 & 427 & $4 \mathrm{OI}$ & 97 & 5.758 \\
\hline 1635 & I.I3O & 1.260 & 1.063 & 719 & 250 & $4 \mathrm{I} 2$ & $49 \mathrm{I}$ & $4 \mathrm{I} 7$ & 87 & 5.829 \\
\hline 1636 & I.I92 & $\mathrm{I} .2 \mathrm{I} 5$ & I.II6 & $72 \mathrm{I}$ & 227 & 415 & 454 & 448 & 106 & 5.894 \\
\hline 1637 & I.088 & I.I98 & I.I34 & 709 & 239 & 394 & 505 & 429 & 73 & 5.769 \\
\hline 1638 & $\mathrm{I} .2 \mathrm{IO}$ & I.226 & I.O88 & $65 \mathrm{I}$ & 255 & 390 & 423 & 379 & $8 \mathrm{I}$ & 5.703 \\
\hline 1639 & 1.216 & I. 386 & I.OII & 696 & 256 & 457 & 499 & 409 & 83 & 6.013 \\
\hline 1640 & I.I 58 & I.I7I & I.084 & 683 & 235 & $43 \mathrm{I}$ & 454 & 406 & 66 & 5.689 \\
\hline I64I & I. 278 & $\mathrm{I} .4 \mathrm{IO}$ & 859 & 587 & I93 & 435 & 448 & 369 & 82 & 5.660 \\
\hline 1642 & I.I37 & I. 374 & $8 \mathrm{I} 5$ & 550 & 195 & 448 & 472 & 456 & IOI & 5.547 \\
\hline I643 & 1.256 & I.319 & 899 & 625 & I83 & 346 & $4 \mathrm{I} 4$ & $3 \mathrm{I} 3$ & 83 & 5.437 \\
\hline I644 & 1.052 & I.I 57 & 944 & 512 & I86 & 334 & 382 & 396 & 86 & 5.048 \\
\hline I645 & I.IIO & 1.263 & 762 & 565 & 199 & 359 & 434 & 346 & 75 & $5 . \mathrm{II} 2$ \\
\hline 1646 & I.I78 & $\mathrm{I} .232$ & 948 & 647 & 206 & 398 & 450 & 279 & 92 & 5.430 \\
\hline I647 & $\mathrm{I} .2 \mathrm{I} 3$ & $\mathrm{I} .338$ & 966 & 519 & $2 \mathrm{I} 2$ & $38 \mathrm{I}$ & 436 & 267 & 38 & 5.370 \\
\hline 1648 & I.I87 & I.2II & 892 & 545 & $\mathrm{I} 74$ & 390 & 459 & 290 & 62 & $5.2 \mathrm{II}$ \\
\hline I649 & I.299 & 1.365 & 998 & 603 & 97 & 458 & 500 & 268 & 73 & $5.66 \mathrm{I}$ \\
\hline 1650 & I. 268 & 1.230 & 862 & 555 & $\mathrm{I} 23$ & $43 \mathrm{I}$ & 476 & 270 & 89 & 5.305 \\
\hline $165 \mathrm{I}$ & I.OI5 & I.II3 & 846 & 495 & $\mathrm{I} 42$ & 379 & $45 \mathrm{I}$ & 270 & 79 & $4.79 \mathrm{I}$ \\
\hline 1652 & 900 & I.I2O & 694 & $4 \mathrm{I} 6$ & 155 & 429 & $44 \mathrm{I}$ & $24 \mathrm{I}$ & 9I & 4.487 \\
\hline 1653 & I.085 & I.I85 & 836 & 474 & 195 & 423 & 478 & 255 & 95 & 5.026 \\
\hline 1654 & I.I75 & 988 & 886 & 637 & I86 & 408 & 500 & 304 & 70 & 5.154 \\
\hline 1655 & I.III & 988 & 917 & 553 & 183 & $3 \mathrm{I} 2$ & $4 \mathrm{I} 3$ & 299 & 62 & 4.838 \\
\hline 1656 & I.I66 & I.OOI & 953 & 549 & $\mathrm{I} 88$ & 352 & 352 & 300 & 38 & 4.899 \\
\hline 1657 & I.083 & 1.003 & $85 \mathrm{I}$ & 623 & 189 & $4 \mathrm{II}$ & 488 & $3 \mathrm{I} 2$ & 69 & 5.028 \\
\hline
\end{tabular}




\begin{tabular}{|c|c|c|c|c|c|c|c|c|c|c|}
\hline \multirow[b]{2}{*}{ Sèries } & \multicolumn{10}{|c|}{ Evolució anual dels baptismes a Catalunya (I600-I700) per regions } \\
\hline & 48 & 26 & 24 & 37 & 3 & 16 & I8 & 8 & 3 & I83 \\
\hline & regió I & regió 2 & regió 3 & regió 4 & regiós & regió 6 & regió 7 & regió 8 & regió 9 & Catalunya \\
\hline 1658 & I.I3O & 955 & I.024 & 593 & 223 & 365 & 398 & 299 & 43 & 5.029 \\
\hline 1659 & I.076 & I.O43 & 967 & 589 & I97 & 352 & 447 & 317 & 67 & 5.054 \\
\hline 1660 & I.II9 & I.083 & $88 \mathrm{I}$ & 629 & 203 & 399 & 435 & 355 & 80 & 5.184 \\
\hline I66I & I.IO3 & I.053 & 935 & 564 & 227 & 417 & 440 & 293 & 72 & 5.105 \\
\hline 1662 & 1.007 & I.084 & 907 & 536 & 183 & 403 & 385 & $27 \mathrm{I}$ & 55 & $4.83 \mathrm{I}$ \\
\hline 1663 & I.O24 & I.094 & 840 & 560 & 217 & 417 & 384 & 293 & 74 & 4.903 \\
\hline 1664 & I.I79 & I.084 & 983 & 617 & $2 \mathrm{I} 4$ & 455 & 449 & 320 & 75 & 5.376 \\
\hline 1665 & 995 & I.220 & 873 & 535 & 218 & 435 & 429 & 321 & 6I & 5.087 \\
\hline 1666 & I. 222 & I.2II & 857 & 6I4 & 200 & 420 & $4 \mathrm{I} 4$ & 329 & 80 & 5.347 \\
\hline 1667 & 1.165 & I.235 & $88 \mathrm{I}$ & 580 & I93 & 478 & 455 & 276 & 82 & 5.346 \\
\hline 1668 & I.I9O & I.294 & 847 & 632 & 209 & 462 & $42 \mathrm{I}$ & 338 & 80 & 5.473 \\
\hline 1669 & I.I88 & $\mathrm{I} .220$ & 948 & 554 & 192 & 476 & $4 \mathrm{I} 5$ & 278 & 66 & 5.338 \\
\hline 1670 & I.ISI & I.199 & 799 & 554 & I64 & 447 & 408 & 287 & 69 & 5.078 \\
\hline 1671 & I. 200 & I. 343 & 993 & 613 & 217 & 477 & 474 & 309 & 88 & 5.714 \\
\hline 1672 & I.I92 & 1.219 & 902 & 576 & 182 & 446 & 432 & 344 & 96 & 5.389 \\
\hline 1673 & 1.089 & $\mathrm{I} .272$ & 835 & $6 \mathrm{I} 4$ & 160 & 502 & $45 \mathrm{I}$ & $32 \mathrm{I}$ & $7 \mathrm{I}$ & $5.3 \mathrm{I} 4$ \\
\hline 1674 & I.I24 & I. 243 & 898 & 590 & I8I & $47 \mathrm{I}$ & 490 & 333 & 82 & $5.4 \mathrm{I} 2$ \\
\hline 1675 & I.I97 & I.26I & 905 & 624 & 206 & $47 \mathrm{I}$ & 473 & 348 & 70 & 5.554 \\
\hline 1676 & I.I65 & $\mathrm{I} .2 \mathrm{I} 2$ & 925 & 633 & I8O & $5 \mathrm{II}$ & $49 \mathrm{I}$ & 352 & 54 & 5.522 \\
\hline 1677 & 1.236 & $\mathrm{I} .282$ & 99I & 680 & 205 & 453 & 543 & 362 & 78 & 5.830 \\
\hline 1678 & I.I37 & I.I68 & 916 & 563 & 193 & 452 & 467 & 299 & 66 & 5.260 \\
\hline 1679 & I.II3 & I.I36 & 897 & 663 & I99 & 448 & 483 & 399 & 55 & 5.393 \\
\hline 1680 & I. 303 & 1.295 & 959 & 652 & 230 & $5 \mathrm{I} 2$ & 543 & 395 & 80 & 5.969 \\
\hline $\mathrm{I} 68 \mathrm{I}$ & I.I97 & $\mathrm{I} .23 \mathrm{I}$ & $97 \mathrm{I}$ & 639 & 193 & 456 & 485 & 350 & $8 \mathrm{I}$ & 5.603 \\
\hline 1682 & I.3OI & I. 343 & 954 & 632 & 239 & 527 & 479 & 367 & 75 & 5.917 \\
\hline 1683 & I.297 & 1.309 & 990 & 709 & 239 & 528 & 483 & 373 & 88 & 6.016 \\
\hline 1684 & I.I74 & 1.295 & 899 & 595 & 221 & 502 & 504 & 362 & 79 & 5.632 \\
\hline 1685 & 1.090 & I. 223 & 925 & 662 & 215 & 498 & 487 & $35 \mathrm{I}$ & 70 & $5.52 \mathrm{I}$ \\
\hline 1686 & I. $38 \mathrm{I}$ & $\mathrm{I} .4 \mathrm{I} 3$ & $98 \mathrm{I}$ & 783 & $25 \mathrm{I}$ & 587 & 542 & $4 \mathrm{OI}$ & 80 & 6.418 \\
\hline I687 & 1.216 & I. 227 & I.038 & 701 & 249 & 489 & 493 & 360 & 74 & 5.846 \\
\hline
\end{tabular}

(Continua a la pàgina següent)

Pedralbes, 4I (202I), 9I-I42, ISSN: O2II-9587, DOI: IO.344/PEDRALBES2O2I.4I.3 


\begin{tabular}{|c|c|c|c|c|c|c|c|c|c|c|}
\hline \multirow[b]{2}{*}{ Sèries } & \multicolumn{10}{|c|}{ Evolució anual dels baptismes a Catalunya (I600-1700) per regions } \\
\hline & 48 & 26 & 24 & 37 & 3 & 16 & I8 & 8 & 3 & 183 \\
\hline & regió I & regió 2 & regió 3 & regió 4 & regió 5 & regió 6 & regió 7 & regió 8 & regió 9 & Catalunya \\
\hline I688 & I. 329 & I. 378 & I.O28 & 750 & 250 & 574 & 496 & 394 & IOO & 6.299 \\
\hline 1689 & I. 382 & I. $42 \mathrm{I}$ & I.IO3 & 776 & 245 & 542 & 494 & 358 & 84 & 6.405 \\
\hline 1690 & I. 397 & I. 423 & I.II6 & 780 & 268 & 583 & 523 & 384 & 85 & 6.559 \\
\hline I69I & $\mathrm{I} .408$ & 1.506 & I.O3I & 803 & 265 & 530 & $47 \mathrm{I}$ & 395 & 88 & 6.497 \\
\hline 1692 & I.319 & I. 442 & I. 074 & 706 & 248 & 568 & 460 & 374 & 74 & 6.265 \\
\hline I693 & I. 462 & I. 408 & 1.069 & 829 & 307 & $5 \mathrm{IO}$ & 539 & 407 & 92 & 6.624 \\
\hline 1694 & I. 449 & I. 443 & I.I22 & 776 & 309 & 520 & 495 & 416 & 94 & 6.624 \\
\hline 1695 & I. 350 & I. 208 & I.O9I & 778 & 249 & 555 & 527 & 378 & 95 & 6.230 \\
\hline 1696 & I. $4 \mathrm{I} 7$ & I. 300 & I. 232 & 870 & $3 \mathrm{I} 7$ & 517 & 512 & 379 & 85 & 6.629 \\
\hline I697 & I. 508 & I.297 & I.229 & 790 & 263 & 508 & 561 & $4 \mathrm{I} 3$ & 82 & 6.652 \\
\hline I698 & I. 452 & I.44I & I.I92 & 839 & 309 & 545 & 505 & 407 & 90 & 6.782 \\
\hline 1699 & I. 634 & 1.606 & I.297 & 852 & $3 \mathrm{I} 4$ & 584 & 617 & 463 & 94 & $7.46 \mathrm{I}$ \\
\hline I7OO & I. 598 & I. 384 & I.255 & 824 & 290 & 574 & 524 & 287 & 82 & 6.818 \\
\hline$\%$ població & $3 I, 6$ & 26,9 & 46,7 & 42,0 & 40,6 & I9,8 & $\mathrm{I} 7,8$ & 17,3 & 4,9 & $27, \mathrm{I}$ \\
\hline
\end{tabular}

